\title{
SUBLETHAL EFFECTS OF BIOLOGICALLY TREATED \\ PETROLEUM REFINERY WASTEWATERS ON \\ AGONISTIC BEHAVIOR OF MALE \\ ORANGESPOTTED SUNFISH, \\ LEPOMIS HUMILIS \\ (GIRARD)
}

l

\author{
By \\ JAMES CARROLL PETERSEN \\ Bachelor of Science \\ University of South Dakota \\ Vermillion, South Dakota
}

1975

\author{
Submitted to the Faculty of the Graduate College \\ of the Oklahoma State University \\ in partial fulfillment of the requirements \\ for the Degree of \\ MASTER OF SCIENCE \\ December, 1979
}




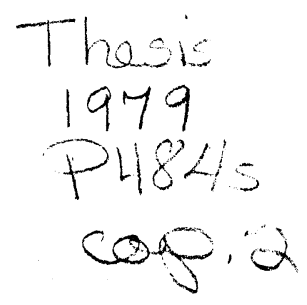




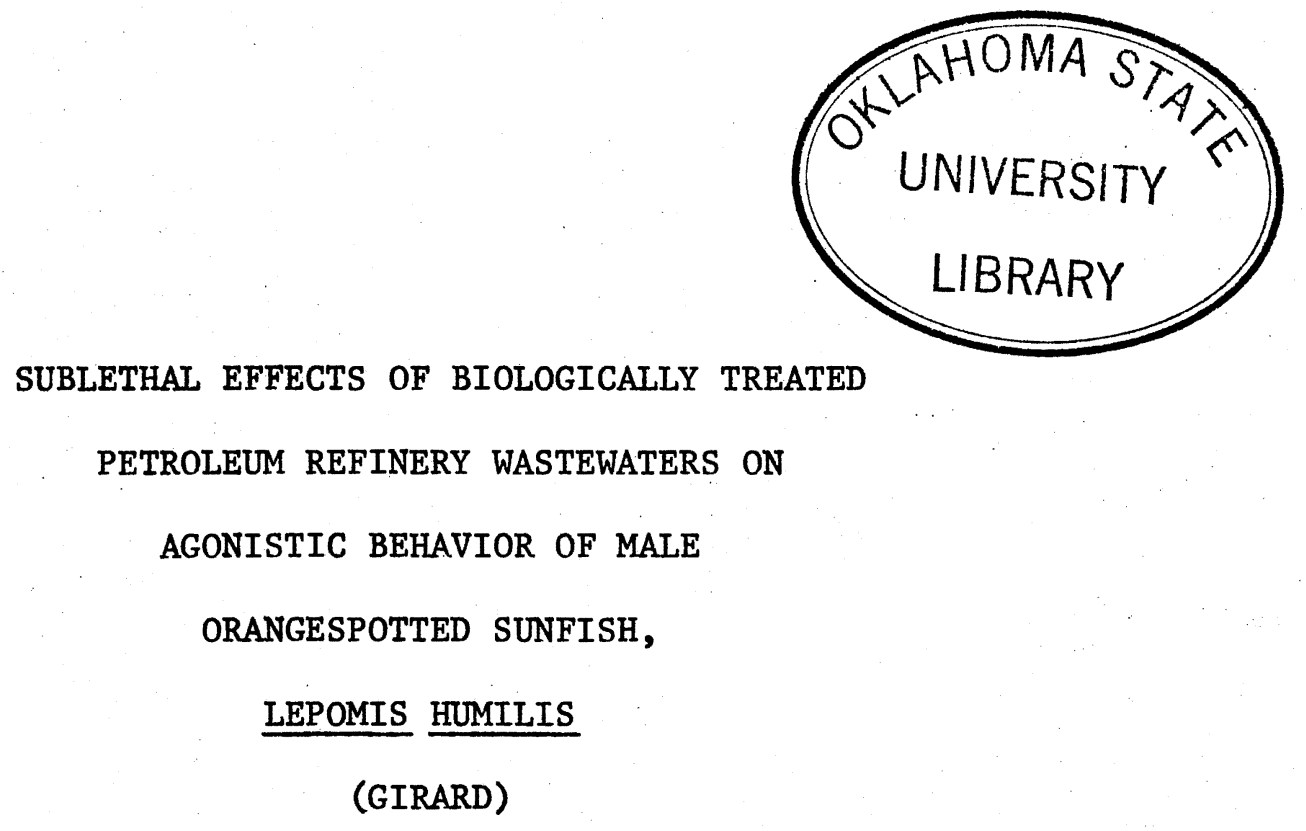

Thesis Approved:

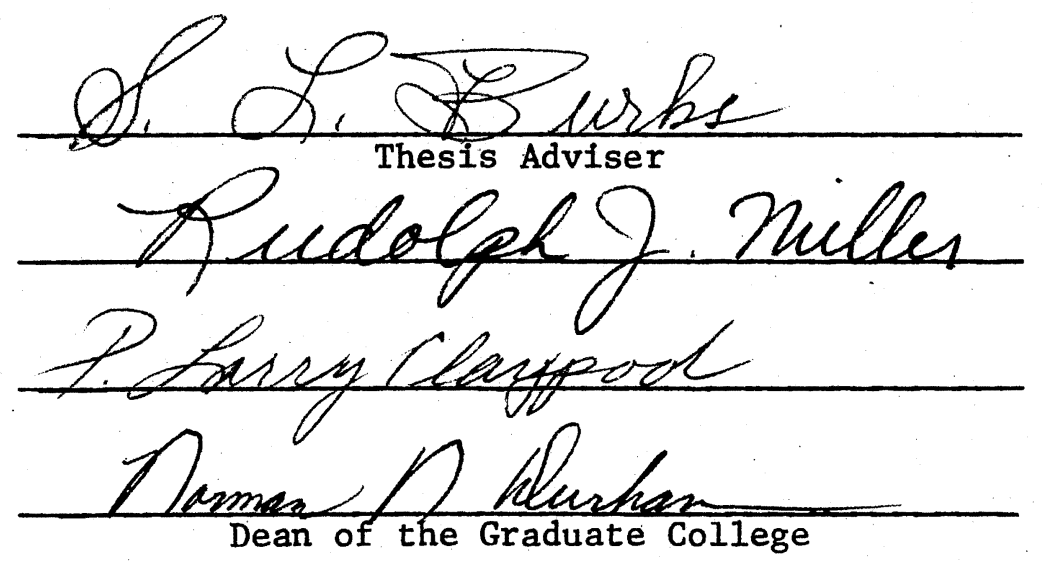

1043032 


\section{ACKNOWLEDGMENTS}

I would like to express my gratitude to several people and organizations for their assistance with this research. I would like to thank Dr. Sterling L. Burks for serving as thesis adviser and for his conscientious assistance and support during all phases of the research. Drs. Rudolph J. Miller and William Warde served on the advisory committee and assisted greatly with the design of the experiment and also provided constructive criticisms of the manuscript. Dr. Larry Claypool graciously served as a committee member and commented on the manuscript. Mary Leida examined fish for parasites.

I would like to express my appreciation to the National Wildlife Federation and the American Petroleum Institute for financial support from September 1977 to May 1978. The support of the Oil Refiners' Waste Water Council is appreciated and the refinery where wastewaters were bioassayed is also thanked for its cooperation.

I would like to thank my parents, Alfed and Doris, and my wife, Tricia, for their support and inspiration. 
TABLE OF CONTENTS

Chapter

Page

I. INTRODUCTION ...................... 1

Objectives of Research . . . . . . . . . . . . 1

Significance of Behavioral Responses . . . . . . . 2

Previous Studies of Sublethal Behavioral Changes . . . . 3

Significance of Agonistic Behavior in Bioassays . . . . 6

Selection of the Orangespotted Sunfish for Bioassay . . 7

Description of the Refinery . . . . . . . . . 8

II. MATERIALS AND METHODS . . . . . . . . . . . . . . 9

Collection and Handling of Fish . . . . . . . . 9

Description of Aquaria . . . . . . . . . . 10

Bioassay Methods . . . . . . . . . . . . 11

Behavioral Observations . . . . . . . . . . 15

Chemical and Physical Observations . . . . . . . 17

III. RESULTS . . . . . . . . . . . . . . . . 19

Changes in Agontstic Behavior . . . . . . . . . 19

Seasonal Variation in Agonistic Behavior Rates . . . . 25 Mortalities and Non-Quantified Sublethal Effects

in Bioassays 4, 5 and 6 ............. 25

Physicochemical Parameters . . . . . . . . . 30

Calculation of Daily Means . . . . . . . 30

Temperature ................ 30

Dissolved Oxygen .............. 32

Conductivity . . . . . . . . . . . . 32

$\mathrm{pH} \cdot$. . . . . . . . . . . . . . . . 35

Alkalinity ................ 35

Hardness ................. 35

Carbon Dioxide . . . . ......... . 39

Total Organic Carbon . . . . . . . . . . 39

Heavy Metals . . . . . . . . . . . 42

IV. CONCLUSIONS . . . . . . . . . . . . . . . . . 44

V. DISCUSSION AND RECOMMENDATIONS . . . . . . . . . . . 46

LITERATURE CITED . . . . . . . . . . . . . . . . 50 


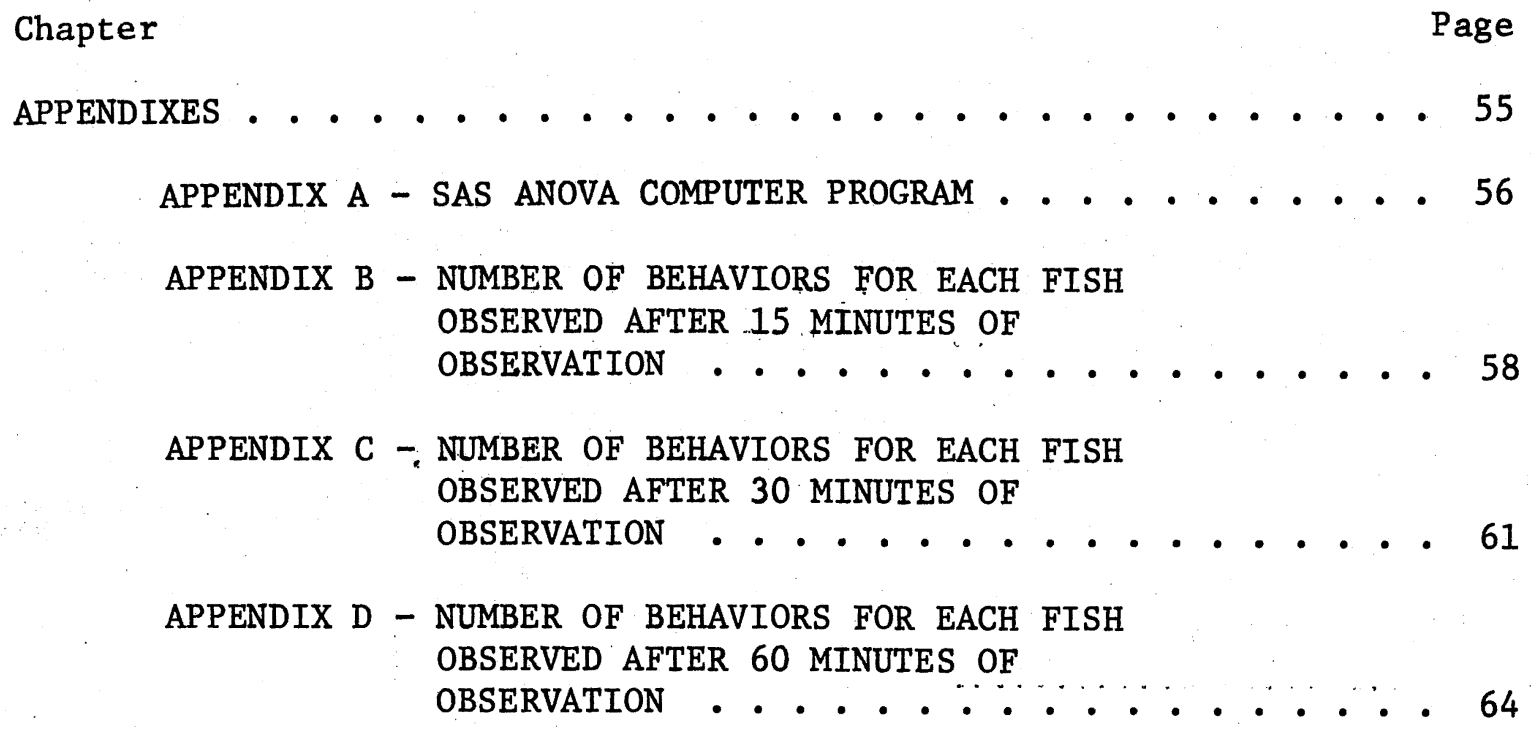




\section{LIST OF TABLES}

Table

Page

I. Chemical Analyses of Control Water . . . . . . . . 10

II. Results of Statistical Analysis of Treatment, Run, and Interaction Effects After 60 Minutes of Observation . . . 21

III. Results of Statistical Analysis of Treatment, Run, and Interaction Effects After 30 Minutes of Observation . . . 23

IV. Results of Statistical Analysis of Treatment, Run, and Interaction Effects After 15 Minutes of Observation . . . 26

v. Mean Daily Temperature in Bioassay Aquaria . . . . . 31

VI. Mean Daily Dissolved Oxygen Concentration in Bioassay Aquaria .................... 33

VII. Mean Daily Conductivity in Bioassay Aquaria . . . . . . 34

VIII. Mean Daily $\mathrm{pH}$ in Bioassay Aquaria . . . . . . . . 36

IX. Mean Daily Total Alkalinity in Bioassay Aquaria . . . . 37

X. Mean Daily Hardness in Bioassay Aquaria . . . . . . 38

XI. Mean Daily $\mathrm{CO}_{2}$ Concentration in Bioassay Aquaria . . . . 40

XII. Mean Total Organic Carbon and Number of Mortalities in Treatment Aquaria . . . . . . . . . . 41

XIII. Mean Chromium, Lead, and Zinc Concentrations and Number of Mortalities in Treatment Aquaria . . . . . . . . 43 
LIST OF FIGURES

Figure

Page

1. Control, Treatment, and Observation Aquaria with

Removable Partitions . . . . . . . . . . . . 12

2. Mean Treatment and Control $\Delta$ Values After 60 Minutes of Observation . . . . . . . . . . . . . . . 22

3. Mean Treatment and Control $\Delta$ Values After 30 Minutes of Observation . . . . . . . . . . . . . . 24

4. Mean Treatment and Control $\Delta$ Values After 15 Minutes of Observation ................. 27

5. Seasonal Comparison of Behavioral Frequencies . . . . . . 28 
CHAPTER I

\section{INTRODUCTION}

Objectives of Research

In recent years the petroleum refining industry has improved the quality of its wastewaters by installing activated sludge systems, biological waste stabilization lagoon systems, or combinations of both in order to meet 1977 effluent criteria set as a result of the Federal Water Pollution Control Act of 1972 (PL 92-500). This has resulted in the reduction of acute lethal effects upon organisms in receiving waters.

In the past the majority of bioassays of toxic substances, including petroleum refinery wastewaters, have investigated the short term lethal effects of these substances on organisms. Improvement in the quality of refinery wastewaters has stimulated the need for investigations of various chronic and sublethal physiological and behavioral responses in order to more adequately assess the total effect of these wastewaters. The primary objective of this research was to investigate sublethal effects of biologically treated petroleum refinery wastewaters through observations of the agonistic behavioral responses of fish.

The second major objective of this study was to develop a relatively fast method for detection of sublethal deleterious effects without the use of time consuming chronic or life-cycle bioassays. Dicks (1976) recognized the significance of using behavioral responses to bridge the 
gap between acute lethal bioassays and more time consuming chronic bioassays and field investigations.

\section{Significance of Behavioral Responses}

Several authorities have stressed the necessity for research on the effects of sublethal levels of pollutants on avoidance reactions, reproduction, and other normal behavior patterns in order to more accurately assess effects of contaminants for establishment of ecologically sound water quality criteria (Warner et a1., 1966; Sticke1, 1969; Sprague, 1971; Baker, 1976; Sprague, 1976).

For several reasons, it is important that consideration be given to behavioral changes in response to pollutants. First, it is likely that evolutionarily stable behavior has distinct survival value to organisms in their natural habitat and that any changes in behavior are 1ikely to be deleterious (Warner et al., 1966). Behavioral changes also appear to be very sensitive indicators of pollution (Sprague, 1971). Weir and Hine (1970) found that a very small fraction of the $48 \mathrm{~h}$ LC50 for various metals was sufficient to cause significant impairment of the ability of goldfish (Carassius auratus) to respond to a previously conditioned response. Concentrations of less than $1 / 1570(0.066 \%)$ of the $48 \mathrm{~h}$ LC50 for lead were sufficient to cause impairment of the ability of goldfish to respond to a flashing light and avoid a mild electric shock. Warner (1967, p. 191) called behavioral changes ". . the most sensitive indicator yet developed of toxicant-induced change in living systems." Warner et al. (1966) and Scherer (1977) further support the use of behavioral bioassays by stating that behavioral changes are more comprehensive than physiological or biochemical changes. 
Previous Studies of Sublethal

Behavioral Changes

In recent years there has been an increase in the emphasis placed upon the study of sublethal behavioral changes resulting from exposure to pollutants. Many of these studies involved changes in behavior as a result of pesticide exposure. These studies include investigations of the effects of fenitrothion on locomotion, feeding and social behavior of coho salmon (Bull and McInerney, 1975), fenitrothion on the ability of juvenile Atlantic salmon to hold territories (Symons, 1973), DDT on exploratory behavior on goldfish (Davy et al., 1973), DDT on light discrimination and learning by rainbow trout (McNicholl and MacKay, 1975a and 1975b), sevin on schooling behavior of Menidia (Weis and Weis, 1975), and parathion on susceptibility of shrimp to predation (Farr, 1977).

Although the majority of research dealing with sublethal behavioral changes appears to be associated with pesticide exposures, there have been several studies investigating sublethal behavioral effects of exposure to various metals. Effects include disruption of Atlantic salmon migration by copper and zinc (Sprague et al., 1965), reduced settlement of oyster spat as a result of zinc exposure (Boyden et al., 1975), extinction of a previously conditioned response in goldfish caused by several heavy metals (Weir and Hine, 1970), and increased susceptibility of Gambusia to predation as a result of sublethal exposure to mercury (Kania and O'Hara, 1974).

Studies of behavioral changes of aquat1c organisms following exposure to various petrochemicals have been concerned primarily with 
the effects of oil spills. Krebs and Burns (1977) Investigated the effects of a fuel oil spill on locomotor and burrowing behavior, molting coloration, and molting of the crab, Uca pugnax. Limpets exposed to a simulated crude oil spill detach from the substrate at higher than normal rates (Dicks, 1973). A lengthy review of the behavioral effects of various petroleum components has been compiled by Clark and Brown (1977). These include narcosis caused by volatile normal paraffins, interference with nutrition and chemoreception after exposure to nonvolatile paraffins and numerous chronic effects of aromatic hydrocarbons. Johnson (1977) presents an extensive review of various changes in behavior of bacteria, algae, and invertebrates. These include inhibition of chemosensory attraction of bacteria to prey and color changes, disruption of locomotor behavior, changes in respiratory movement rates, narcosis and elimination of reproductive behavior in invertebrates. Pattern (1977) reviews the sublethal effects of petroleum hydrocarbons on fish behavior. These effects include changes in avoidance reactions, cough responses, increases and decreases in swimming activity, disruption of schooling behavior, and narcosis.

Fewer studies have investigated the sublethal behavioral effects of oil refinery wastewaters. Dicks (1976) reported a lowered settlement density of the cyprid stage of the barnacle, Balanus balanoides, near a refinery outfall. Laboratory studies of the effects of this wastewater on the earlier nauplii stage of $\underline{B}$. balanoides indicated that there was a reduction of swimming activity. However, the lower salinity of the wastewater ( 9 p.p.t. vs. 34 p.p.t. for seawater) was indicated to be at least as important as other characteristics of the wastewater in reducing swimming activity. Also in laboratory tests, Parsons (1972; cited 
by Dicks, 1976) found that refinery wastewaters reduced the locomotor activity of the grooved periwinkle, Littorina saxatilis. Dicks (1976) reports large numbers of the oligochaete Nereis diversicolor leaving their burrows in response to an accidental discharge of refinery wastewater. The Nereis were then extensively fed upon by sea birds. This sublethal behavioral response resulted in an observable ecological effect and was found to be due to factors other than salinity change (Baker, 1976).

Three petroleum refinery wastewater treatment methods were evaluated using bioassays by Burks and Wilhm (1978) and Kleinholz (1978). Fathead minnows (Pimephales promelas) and assemblages of benthic macroinvertebrates were exposed to the wastewaters during 32-day static and continuous flow bioassays. The treatment methods evaluated were: (1) activated sludge treatment, (2) activated sludge treatment followed by dual media (sand and anthracite coal) filtration, and (3) activated sludge treatment and dual media filtration followed by adsorption on activated carbon. Male fathead minnows displayed spawning behavior consisting of establishment, defense, and cleaning of spawning sites during one of the bioassays. Vertical color bars and rostral tubercles, which are secondary sexual characteristics, were seen in these males. These spawning behaviors were observed only in minnows exposed to control water or to wastewater which had been treated by the activated sludge-dual media-activated carbon method. Other sublethal behavioral effects of treated petroleum refinery wastewaters on fathead minnows have been reported by Graham (1963) and Graham and Dorris (1968). Graham observed loss of schooling behavior, loss of appetite, sluggishness, slow 
or absent response to a disturbance, and lowered index of condition (even for fish which seemed to be feeding normaliy).

Sprague et al. (1978) investigated sublethal behavioral effects of treated petroleum refinery wastewaters in a laboratory study dealing with rainbow trout (Salmo gairdneri), flagfish (Jordanella floridae), and the invertebrate Daphnia pulex. The wastewater used was generally in compliance with Canadian regulations governing physicochemical parameters and non-lethality to rainbow trout. Sublethal effects examined included effects on growth, avoidance reactions, locomotor reactions and cough responses of rainbow trout; effects on growth and reproduction of flagfish; and effects of reproduction of Daphnia. The threshold for most of the effects just mentioned was generally calculated to be at about $10 \%$ effluent $/ 90 \%$ dilution water. Dilutions of as 1ow as $0.52 \%$ effluent were calculated to be the threshold for $5 \%$ inhibition of Daphnia pulex reproduction.

\section{Significance of Agonistic Behavior in Bioassays}

Agonistic behavior, which involves fighting and competitive behavior, attacks and escapes has recognizable benefits for individuals and populations (Johnsgard, 1967; Johnson, 1972). It may be used for establishment of territories for breeding, feeding and shelter. Crook (1970) notes that territory operates as a "social mortality factor," allowing holders of territory to escape predation and increase success of breeding activities. In other situations limited space for territories can limit overpopulation and favor the survival of healthier individuals (Johnson, 1972). The common repertoire of agonistic 
behaviors of various centrarchlds has already been studied extensively both in the laboratory (Miller, 1963; Hadley, 1969; Dennis, 1970; Powe11, 1972) and in the field (Barney and Anson, 1923; Breder, 1936; Witt and Marzolf, 1954; Hunter, 1963; Miller, 1963; Boyer, 1969). Ecological significance and existing knowledge of centrarchid agonistic behavior, coupled with the previously discussed sensitivity and comprehensiveness of behavioral bioassays, make observation of agonistic behavior changes an appropriate and attractive sublethal bioassay method.

\section{Selection of the Orangespotted Sunfish for Bioassay}

The orangespotted sunfish, Lepomis humilis (Girard), was selected for use in this behavioral bioassay for several reasons. First, it is widely distributed, from North Dakota to Ohio southward to Alabama and Louisiana and throughout the Great Plains from Texas to the Dakotas (Miller and Robison, 1973). In addition, Gould (1962) found $\underline{\text { L. humilis }}$ to be a good fish for oil refinery effluent bioassays. Gould reported that $\underline{L}$. humilis was not statistically different from the fathead minnow (Pimephales promelas) in resistance to oil refinery effluents. The fathead minnow is a widely used bioassay organism. Irwin (1965) also ranked the resistance of the orangespotted sunfish and the fathead minnow to oil refinery effluents. In terms of $96 \mathrm{~h}$ TL50, Irwin found the orangespotted sunfish to be slightly more resistant than the fathead minnow. On a scale of 1 to 100 , with 100 representing the most resistant fish tested (the common guppy, Lebistes reticulatus), L. humilis ranked at 61.80 while $\underline{\mathrm{P}}$. promelas ranked at 49.19 . 
L. humilis are sexually dichromatic. The males have orange to orange-brown spots on their sides; females have brownish spots (Miller, 1963). This allows males and females to be distinguished so that variations in behavior due to sex can be eliminated (Greenberg, 1947; Allee et al., 1948; Erickson, 1967; Hadley, 1969).

Finally, agonistic behavior of the orangespotted sunfish has been studied in the 1aboratory previously (Miller, 1963; Dennis, 1970; Powel1, 1972). This eliminated the need for preliminary investigations of agonistic behavior patterns before they could be used as a measure of sublethal stress from contaminants in petroleum refinery wastewaters.

\section{Description of the Refinery}

The refinery chosen for this study was a class B refinery which processed about 50,000 barrels of crude oil per day. The wastewater treatment system consisted of an API gravity oil separator, activated sludge, sludge clarifier, and a sequence of three polishing lagoons (Burks and Wilhm, 1978). The wastewater was collected near the outlet leaving the final lagoon.

Wastewater from the refinery was selected because it consistently caused low or no acute mortality to fathead minnows in $96 \mathrm{~h}$ static bioassays conducted by the Reservoir Research Center, Oklahoma State University (Burks, S. L., Reservoir Research Center, Oklahoma State University, Personal communication, September 1976). 
CHAPTER II

MATERIALS AND METHODS

Collection and Handling of Fish

Fish to be used in the bioassays were captured with a throw net from Theta Pond on the campus of Oklahoma State University, Stillwater, Oklahoma. To minimize variation in agonistic behavior due to size (Greenberg, 1947; Erickson, 1967; Hadley, 1969; Dennis, 1970) and sex (Greenberg, 1947; Allee et al., 1948; Erickson, 1967; Hadley, 1969), only fish which were between 4.0 and $6.5 \mathrm{~cm}$ in standard length and which were considered to be males were kept to be used for bioassay. Males were selected on the basis of coloration. To assess the accuracy of selection 20 fish thought to be males were collected from Theta Pond on 30 April 1979. Squash mounts of gonadal tissue were made for microscopic examination. Nineteen (95\%) were males and one fish (5\%) appeared to contain some ova.

After capture, a sample of fish to be used in bioassays were examined for parasites as recommended by APHA (1976). Only about half of the fish examined were infected with monogenetic trematodes (1-2 per fish) and no internal parasites were found. Fish were allowed to acclimate to laboratory conditions in a 830 liter fiberglassed holding tank for a period of at least one month before being used in a bioassay. This tank was supplied with dechlorinated water which had been filtered 
through activated carbon (Table I). During this time and during the bioassays fish were fed at least twice per day with a dried flake food.

TABLE I

CHEMICAL ANALYSES OF CONTROL WATER

\begin{abstract}
Alkalinity (total, mg/l $\mathrm{CaCO}_{3}$ )* . . . . . . . . . . . 148
Conductivity $(\mu \mathrm{mhos} / \mathrm{cm}) *$. . . . . . . . . . . . 513

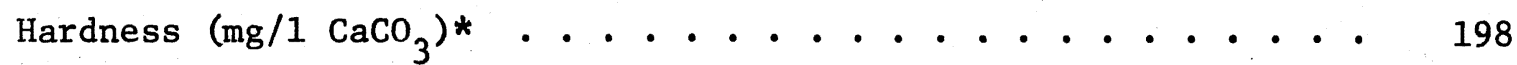

$\mathrm{pH}^{*}$. . . . . . . . . . . . . . . . . . 8.25

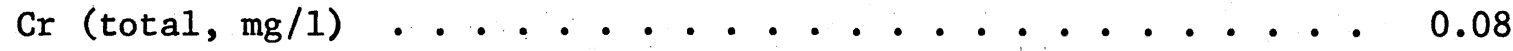

$\mathrm{Cu}(\operatorname{total}, \mathrm{mg} / 1)$. . . . . . . . . . . . . 0.14

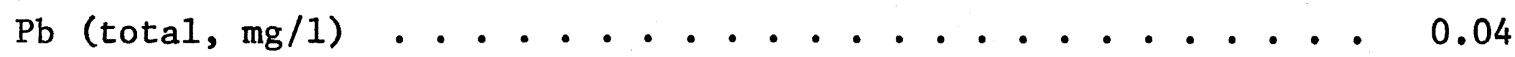

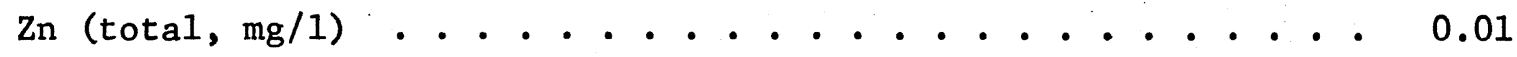

*Values are means of measurements obtained from water in control aquaria on Day 11 (the first day of second half of bioassay) of each of Bioassays 1 through 8 . Metal analyses were of dechlorinated, activated carbon filtered tap water obtained in late 1976.

\title{
Description of Aquaria
}

The six glass aquaria used for the bioassays were $51 \mathrm{~cm}$ long by $26.5 \mathrm{~cm}$ wide by $31 \mathrm{~cm}$ high and could contain a volume of approximately 42 liters. In order to separate individual fish before behavioral observation, each aquarium was divided into four cubicles by three partitions of stainless steel sheeting. The sheeting was held in place 
by guides constructed of sections of microscope slides attached to the aquaria walls with silicone sealant. These partitions allowed water exchange among the cubicles although visual contact between the fish was nearly eliminated. Similar aquaria with only one partition were used for behavioral observation aquaria (Figure 1).

\section{Bioassay Methods.}

The six bioassay aquaria were placed in two rows of three aquaria-one row above the other. Cardboard dividers were placed between the aquaria and at the ends of each row in order to prevent visual contact between fish in adjacent aquaria and also to attempt to keep the amount of light entering each aquarium equal. A $16 \mathrm{~h}$ photoperiod (0700 to 2300 h) was maintained in the room where the bioassays and behavioral observations were conducted. To minimize any influence of sunlight, windows in the room were covered with sheets of black plastic.

Prior to each bioassay 24 fish were removed from the holding tank and their standard lengths measured. Pairings were determined from these measurements--the shortest fish paired with the second shortest fish, the third shortest paired with the fourth shortest, etc. Six of the pairs were then randomly designated control pairs and the remaining six pairs were designated treatment pairs. At this time, for the purpose of distinguishing one individual from the other within a pair, a portion of elther the upper or lower lobe of the caudal fin was removed from each fish. Since caudal fin lobes were removed from control and treatment fish, changes in observed agonistic behavior would not be attributed to fin clipping. 

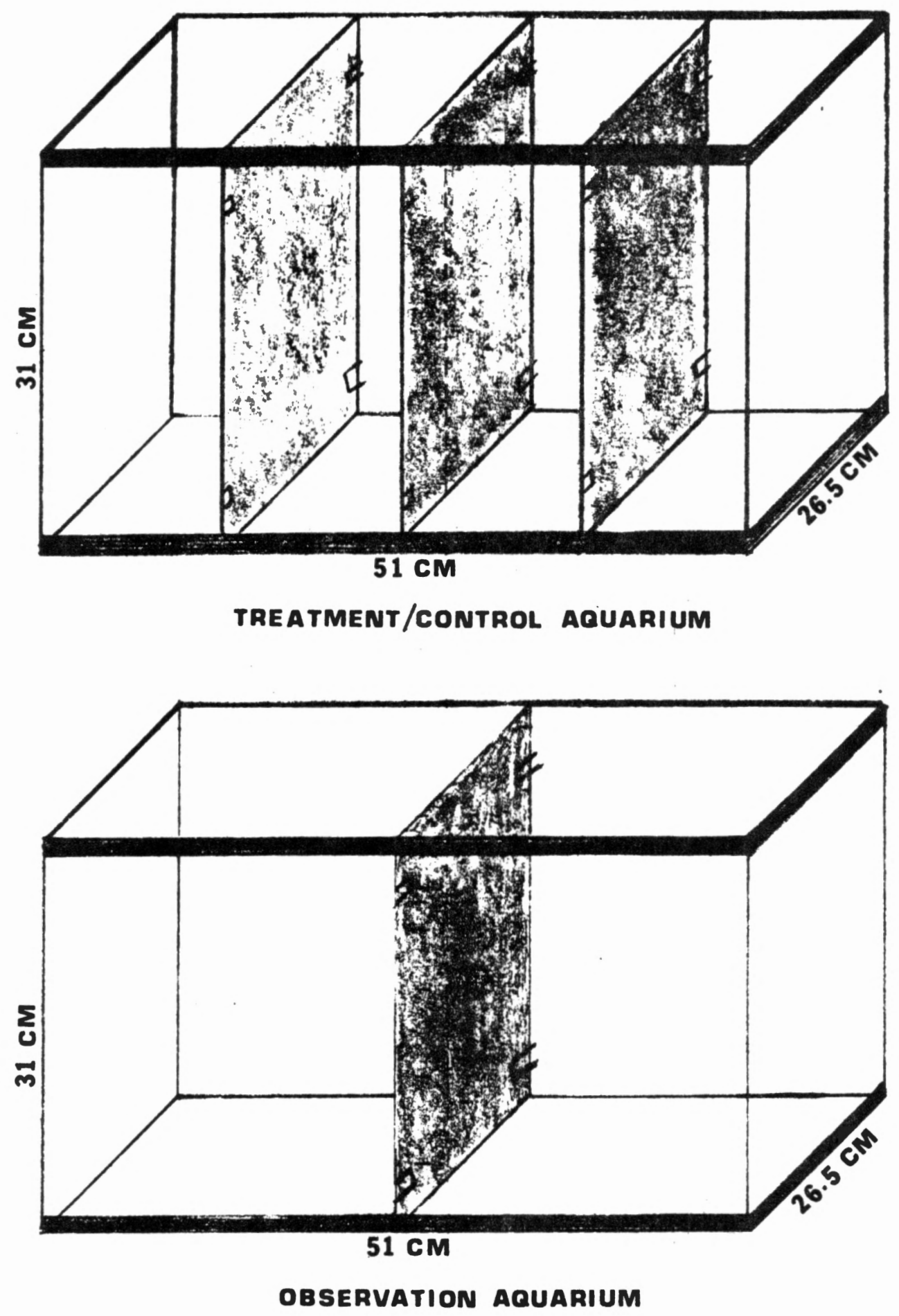

Figure 1. Control, Treatment, and Observation Aquaria with Removable Partitions 
Since the agonistic behavior frequencies of pairs were so variable, it was necessary to establish a "baseline" level of behaviors for each pais of fish. The first 10 days of the bioassay were used for this purpose. All 24 fish were placed in aquaria containing 15 liters of control water which consisted of dechlorinated tap water filtered through activated carbon. The second 10 days of the bioassay were used to expose the fish pairs to either the treatment or control condition. The selection of 10 day periods was somewhat arbitrary, although it was influenced by Graham and Dorris (1968) who reported that fathead minnows exposed to low toxicity refinery wastewaters exhibited a sharp increase in stress behaviors and deaths after 7 to 10 days. From the standpoint of an agonistic behavioral study, this 10 day period also corresponds favorably with pre-observation isolation periods of three days used by Dennis (1970) and Powell (1972) and 14 days used by Hadley (1969).

On the same day (Day 0 ) that the fish were measured, they were placed in the control or treatment aquaria-one fish per cubicle. Aquaria were randomly designated as control or treatment aquaria. To minimize the possibility of intrapair auditory or olfactory communication, individuals of any one pair were placed in separate aquaria. Fish within a single aquarium were either all control or all treatment fish. It was impractical to transport quantities of water adequate for recommended flow rates (APHA, 1975) for continuous-flow bioassays. However, Clemens and Summers (1952) have reported that toxicity of oil refinery wastewaters to red shiners (Notropis lutrensis) did not change for 20 days when the wastewater was stored at $6^{\circ} \mathrm{C}$ in a capped glass container. It was decided that a static bioassay with periodic 
replenishment with stored wastewater would be used. Biologically treated wastewater was collected from the last of a series of three polishing lagoons. Wastewater was then transported to the laboratory in air-tight 20 Iiter glass jugs and stored at approximately $6^{\circ} \mathrm{C}$. Fresh wastewater was collected for each bioassay.

On the first day of the "baseline" establishment period (Day 0) 15 liters of control water was placed in each aquaria. Then, at two day intervals, an additional two liters of control water was added to each of the aquaria. The water was introduced into the aquaria through four rubber tubes attached to a plastic dispenser. Each tube emptied into a separate cubicle to keep conditions in all cubicles as uniform as possible.

On Day 10, four control pairs and five treatment pairs were randomly chosen from the 12 treatment and control pairs. At approximately one hour intervals these nine pairs were placed in observation aquaria and observed as described in the following section. The fifth treatment pair served as an alternate in the event of mortality among the first four treatment pairs.

On Day 11, the fish were again placed in the same cubicle occupled during the first 10 day period. However, the treatment fish were placed in aquaria containing 15 liters of biologically treated petroleum refinery wastewater, while the control fish were again placed in 15 liters of control water. At two day intervals an additional two 1fters of control water or wastewater were added to the appropriate aquaria.

On Day 21, after a 10 day exposure, the agonistic behavior of eight previously observed pairs of fish was again observed. If no mortalities occurred among the originally observed treatment pairs then the first 
four treatment pairs observed on Day 10 were again observed. If there was a mortality among the first four treatment pairs, the fifth pair was used as an alternate and observed again. If there were mortalities among more than one pair of the previously observed treatment pairs, the bioassay was not considered in any statistical comparison of agonistic behavior changes.

\section{Behavioral Observations}

In pairing the fish for behavioral bouts, it was decided to use pairs of fish in which both individuals were exposed to the wastewater or to the control water in order to eliminate the possibility that a non-affected control fish would stimulate or inhibit the behavior of a treatment fish. This decision was prompted by the investigations of Hale (1956) on the effect of forebrain lesions on the behavior of green sunfish. Hale found that lesioned fish were much less aggressive, but if groups of these fish were placed with some normal fish their aggressive behavior rates were much closer to the rates of normal fish. It is also likely that most of the fish present in a receiving stream would have been exposed to the pollutant.

On Day 10, four pairs of control fish and five pairs of treatment fish were randomly chosen to be observed for one hour periods. The order of observation was also random. Each pair in turn was placed in an observation aquarium (one fish on each side of the partition) and allowed to acclimate for at least one hour but no more than two hours. At the end of the acclimation period the partition was carefully lifted and the fish were observed for one hour. 
Seven behavior patterns were chosen for observation. These behaviors, and definitions (modified from Dennis, 1970, and Powe11, 1972) used as criteria for recording each, are listed below:

1. Approach (AP): An approach was recorded whenever one fish swam into the vicinity of the other and either displayed or elicited a display from the second fish.

2. Fin erection (FE): A fin erection was recorded whenever the medial fins were erected.

3. Bite (BT): A bite was recorded whenever mouth contact was made with an opponent. (Occasionally mutual mouthlocks occurred and a bite was recorded for both fish in these cases.)

4. Chase (CH): A chase was recorded whenever one fish was in direct pursuit of the other.

5. Opercle spread (OP): An opercle spread was recorded whenever the opercle covers were spread or flared away from the head.

6. Tail beat (TB): A tail beat session was recorded whenever the caudal peduncle of a fish was swung from side to side pushing water against the body of the other. As long as the individual beats occurred in succession without pause, only one tail beat was recorded. When the beats were separated by a pause of approximately one second or longer, this pause marked the end of a tail beat session.

7. Avoid (AV): An avoid was recorded whenever a fish, after being approached by the other fish, moved slowly away from the second fish and was not pursued.

8. Total (TOT): A sum of the first six behaviors listed above was computed. Avoids (AV) were not included because they were considered to be generally more submissive than the other six behaviors. 
Al1 observations were recorded on an Esterline-Angus event recorder wired to a keyboard (Frey and Miller, 1972). This allowed a record of frequency, duration and temporal spacing of each behavior for each fish. The appropriate key on the keyboard was pressed for the duration of each behavior observed. Data were then transcribed from the chart paper to a notebook. Cumulative totals at five minute intervals were recorded for each behavior type for individual fish. This allowed behavioral frequencies to be compared at several temporal levels between 5 and 60 minutes.

On Day 21, after exposure to either a second 10 days in control water or to the 10 days in the wastewater, the pairs of fish were again observed. To avoid an effect due to time of day, each pair of fish was observed at approximately the same time on Days 10 and 21 .

The frequency of each behavior for each pair of fish per hour following the first 10 day exposure was designated as $\mathrm{AP}_{10}, \mathrm{FE}_{10}$, etc. This frequency served as a "baseline" to compare with the frequencies observed following the second 10 day exposure $\left(\mathrm{AP}_{20}, \mathrm{FE}_{20}\right.$, etc.).

For each pair of fish the change in frequency of each behavior was calculated :

$$
\begin{aligned}
& \mathrm{AP}_{20}-\mathrm{AP}_{10}=\Delta \mathrm{AP} \\
& \mathrm{FE}_{20}-\mathrm{FE}_{10}=\Delta \mathrm{FE} \text {, etc. }
\end{aligned}
$$

The " $\Delta$ " values for the control pairs and treatment pairs were then compared statistically using a SAS analysis of variance computer program (Barr et al., 1976, see Appendix).

Chemical and Physical Observations

On Days 11, 13, 15, 17, and 19, following the introduction of 
wastewater or control water, water samples were collected from each aquarium. Samples were analyzed for alkalinity, hardness, and $\mathrm{pH}$. Alkalinity and hardness were determined as recommended by APHA (1975). A Beckman Zeromatic $\mathrm{pH}$ meter was used to determine $\mathrm{pH}$. Carbon dioxide concentrations were calculated using the following formula (Lind, 1974): mg $\left.\mathrm{CO}_{2} / 1=1.589 \times 10^{6} \mathrm{HH}^{+}\right] \times \mathrm{mg} / 1$ alkalinity as $\mathrm{HCO}_{3}^{-}$.

On Days 11 through 20, dissolved oxygen and temperature were measured in each aquarium with a YSI Mode1 51B dissolved oxygen meter and a YSI Model 5738 probe. Conductivity was measured with a YSI Mode1 33 Salinity-Conductivity-Temperature Meter.

On Days 11 and 21, water samples were collected from each treatment aquarium in glass bottles for total organic carbon analysis. On Day 21, samples were collected in polyethylene bottles for analysis of chromium, lead and zinc. Samples for metal and TOC analysis were acidified to pH 2 with concentrated nitric acid immediately after collection. Total organic carbon analyses were performed on a Beckman 915 TOC Analyzer. For total metal (i.e., suspended + dissolved) analyses a volume of 100 $\mathrm{m} 1$ of sample was reflux digested twice in $3 \mathrm{ml}$ of concentrated nitric acid and dissolved in $3 \mathrm{ml}$ of $50 \%$ hydrochloric acid for five minutes. The samples were then diluted to $100 \mathrm{ml}$ with $0.2 \mathrm{~N}$ nitric acid (EPA, 1974). Samples were then analyzed with a Varian Techtron Type AA-5 atomic absorption spectrophotometer equipped with a Perkin Elmer HGA-70 heated graphite atomizer accessory. 
CHAPTER III

RESULTS

Changes in Agonistic Behavior

The major objective of this investigation was to evaluate the usefulness of changes in fish behavior for detecting sublethal effects of wastewaters: Therefore, exposures of test fish to oil refinery wastewaters which resulted in acute mortality of more than one fish were not subjected to statistical analysis of the effects of the wastewater on agonistic behavior. Eight bioassays were performed. Three tests (Bioassays 4, 5, and 6) resulted in two or more mortalities and were not included in the statistical analysis. In four tests, no acute mortality occurred during the exposure. In a fifth exposure only one mortality occurred. In these five bioassays (Bioassays $1,2,3,7$, and 8 ) a total of 80 fish were observed. During 160 hours of observation 10,453 approaches, fin erections, tail beat sessions, chases, bites and avoids were recorded.

The $\Delta$ values (i.e., the per pair frequency on Day 21 minus the per pair frequency on Day 10) obtained for each pair of fish were compared statistically. Highly significant $(P<0.01)$ differences were found between control and treatment $\Delta$ values for approaches, bites, and the sum of all behaviors except avoids (i.e., TOT). A significant $(P<0.05)$ difference was found between treatment and control $\Delta$ values for chases: 
and avoids (Table II). For all types of agonistic behavior, except tail beats, the control pairs were generally more active during the second observation period (Day 21) than during the first observation (Day 10). This resulted in positive $\Delta$ values. In contrast, among the treatment pairs, the frequencies were generally reduced on Day 21 (following the 10 day wastewater exposure). This resulted in negative $\Delta$ values for the treatment pairs (Figure 2). The highest $\Delta$ values among the control group were those for fin erections and chases. The most negative $\Delta$ values among the treatment group were those for tail beats (as they were for the control group), chases and bites. Chases and bites would have to be considered the most overtly aggressive behavior types of those observed. It may be significant that these behaviors deviated most from a $\Delta$ value of zero. The greatest deviations from the control $\Delta$ values were again for chases, bites, and also fin erections.

A 60 minute observation period was considered to be more time consuming than desirable for use in routine bioassays for wastewater monitoring. To investigate the feasibility of using shorter observation periods, the cumulative frequencies obtained at the end of 15 and 30 minutes of the 60 minute observation periods were compared using the same methods utilized for the 60 minute observation period. For the 30 minute observation period, significant $(P<0.05)$ differences were found between treatment and control $\Delta$ values for approaches, bites, and avoids. A highly significant $(P<0.01)$ difference in $\Delta$ values of total (TOT) behaviors was found (Table III). A comparison of $\Delta$ values for the various behavior types shows that $\Delta$ values are lower in the treatment group (Figure 3). For the 15 minute observation period, significant $(P<0.05)$ differences were found between the treatment and control $\Delta$ 
TABLE II

RESULTS OF STATISTICAL ANALYSIS OF TREATMENT, RUN, AND INTERACTION EFFECTS AFTER 60 MINUTES OF OBSERVATION

\begin{tabular}{|c|c|c|c|c|}
\hline \multirow[b]{2}{*}{ Behavior } & \multicolumn{4}{|c|}{ Mean Square of Sources of Variation } \\
\hline & $\mathrm{MS}_{\mathrm{TRT}}$ & ${ }_{\mathrm{RUN}^{+}}^{+}$ & ${ }_{\text {RUN }} \times T_{R T}$ & $\overline{\text { MS }_{\text {ERROR }}}$ \\
\hline Approaches & $940.90 * *$ & 202.60 & 59.90 & 109.12 \\
\hline Fin Erections & $4040.10^{+}$ & 2718.63 & 1176.35 & 1053.98 \\
\hline Tail Beats & 62.50 & 99.16 & 164.06 & 176.03 \\
\hline Chases & $3385.60 *$ & 204.09 & 541.41 & 699.18 \\
\hline Bites & $3348.90 * *$ & 445.15 & 广 381.28 & 299.37 \\
\hline Opercle Spreads & 1050.63 & 170.40 & 786.13 & 667.28 \\
\hline Avoids & $96.10 *$ & $37.34 *$ & 28.67 & 13.32 \\
\hline Total & $62805.62 * *$ & 4380.06 & 6790.19 & 6555.73 \\
\hline
\end{tabular}

*Significant $(P<0.05)$ probability of effect. **Highly significant $(P<0.01)$ probability of effect.

${ }^{+}$Approaches significant $(P<0.05)$ probability of effect.

$H_{\text {Run }}$ effect refers to variation between individual bioassays. 


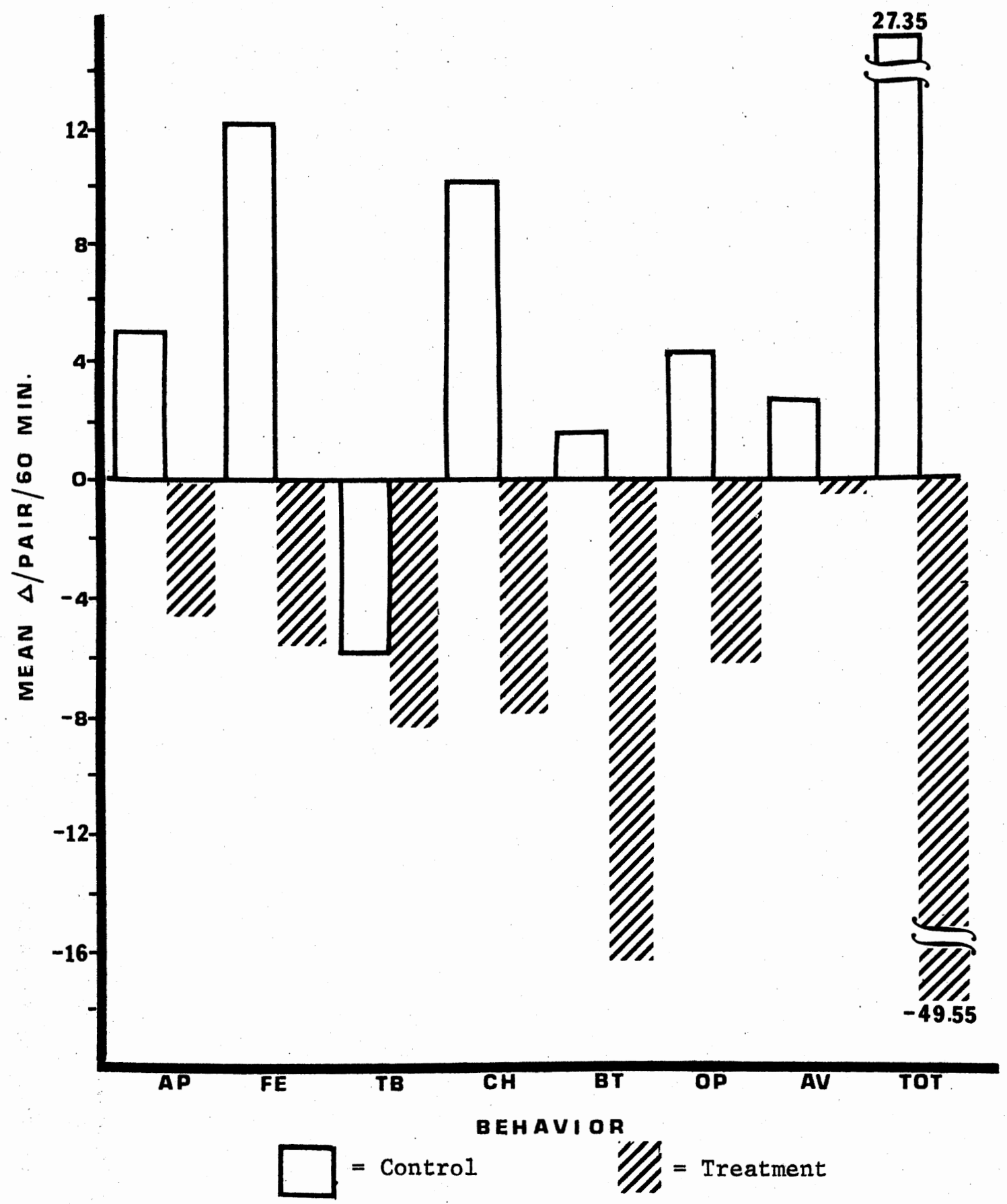

Figure 2. Mean Treatment and Control $\Delta$ Values After 60 Minutes of Observation 
TABLE III

RESULTS OF STATISTICAL ANALYSIS OF TREATMENT, RUN, AND INTERACTION EFFECTS AFTER

30 MINUTES OF OBSFRVATION

\begin{tabular}{lcccr}
\hline \multicolumn{1}{c}{ Behavior } & \multicolumn{4}{c}{ Mean Square of Sources of Variation } \\
\cline { 2 - 4 } & $\mathrm{MS}_{\mathrm{TRT}}$ & $\mathrm{MS}_{\mathrm{RUN}}{ }^{++}$ & $\mathrm{MS}_{\mathrm{RUN}} \times \mathrm{TRT}$ & ${ }_{\text {ERROR }}$ \\
\hline Approaches & $291.60 *$ & 82.96 & 37.04 & 41.93 \\
Fin Erections & $1562.50^{+}$ & 762.10 & 217.63 & 392.48 \\
Tail Beats & 46.23 & $210.46^{+}$ & 38.79 & 81.59 \\
Chases & 455.63 & 147.13 & 50.13 & 156.66 \\
Bites & $462.40 *$ & 110.90 & 56.90 & 73.25 \\
Opercle Spreads & 40.00 & 123.28 & 118.88 & 105.42 \\
Avoids & $48.40 *$ & 15.29 & 12.96 & 7.17 \\
Total & $12673.60 * *$ & 1324.44 & 751.29 & 1637.32 \\
\hline
\end{tabular}

*Significant $(P<0.05)$ probability of effect.

**Highly significant $(\mathrm{P}<0.01)$ probability of effect.

${ }^{+}$Approaches significant $(P<0.05)$ probability of effect.

+ $_{\text {Run }}$ effect refers to variation between individual bioassays. 


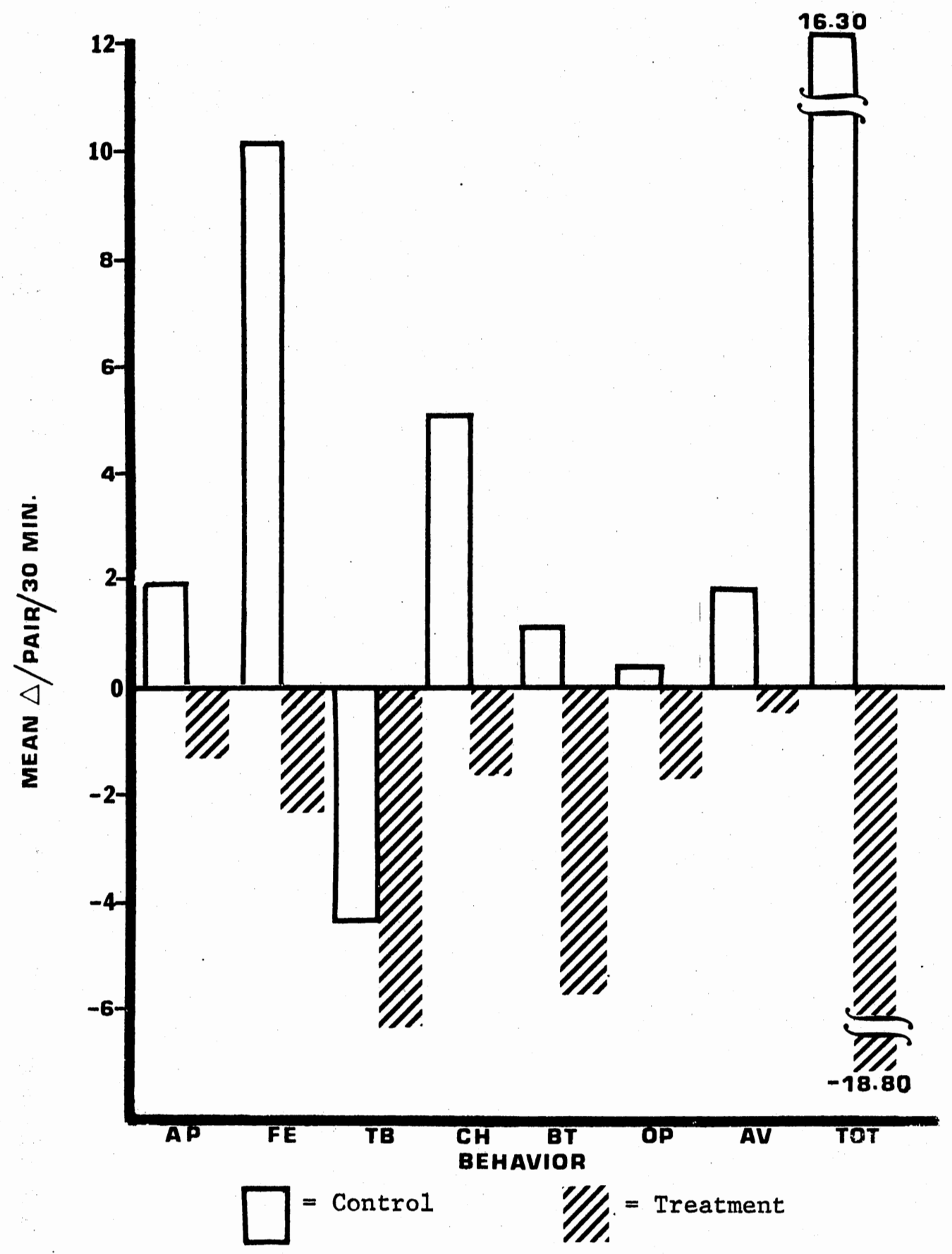

Figure 3. Mean Treatment and Control $\Delta$ Values After 30 Minutes of Observation 
values for approaches and avoids. Highly significant $(P<0.01)$ differences were found for $\Delta$ values of fin erections and TOT (Table IV). Treatment $\Delta$ values are lower than control $\Delta$ values (Figure 4 ).

\section{Seasonal Variation in Agonistic Behavior Rates}

To test for differences in frequency of agonistic behavior rates due to season, the frequency of all behavior types of all pairs of fish observed on Day 10 of Bioassays 1 through 8 were compared using a SAS computer program to perform Duncan's new multiple range test (Steel and Torrie, 1960; Barr et al., 1976). On Day 10 treatment and control fish had been exposed to control conditions only and so both of these groups were considered together. For two types of behaviors, tail beats and bites, the fish of Bioassay 7 were significantly more active than the fish of other bioassays (Figure 5). The number of chases in Bioassay 7 was significantly greater than the number in any of the other bioassays except Bioassay 8. Bioassays 7 and 8 were both conducted during mid-summer. Bioassay 4, conducted during mid-December, usually had the lowest mean frequency of the eight bioassays.

\section{Mortalities and Non-Quantified Sublethal Effects in Bioassays 4,5 and 6}

The wastewaters used in Bioassays 4,5 and 6 were the most toxic of the wastewaters collected. In addition to mortalities, several sublethal and pre-lethal effects were observed. These were changes in eye color, ability to retain equilibrium, feeding habits, and irritability. Except for loss of equilibrium, these changes were observed in non-1ethal 
TABLE IV

RESULTS OF STATISTICAL ANALYSIS OF TREATMENT, RUN, AND INTERACTION EFFECTS AFTER

15 MINUTES OF OBSERVATION

\begin{tabular}{|c|c|c|c|c|}
\hline \multirow[b]{2}{*}{ Behavior } & \multicolumn{4}{|c|}{ Mean Square of Sources of Variation } \\
\hline & $\mathrm{MS}_{\mathrm{TRT}}$ & $\mathrm{MS}_{\mathrm{RUN}}^{+}$ & ${ }^{M S_{R U N}} \times$ TRT & $\overline{\text { MS }_{\text {ERROR }}}$ \\
\hline Approaches & $75.63 *$ & 27.03 & 13.88 & 10.83 \\
\hline Fin Erections & $1010.03 * *$ & 146.94 & 15.96 & 105.36 \\
\hline Tail Beats & 8.10 & 127.06 & 63.29 & 60.33 \\
\hline Chases & 34.23 & 22.85 & 5.73 & 26.08 \\
\hline Bites & 48.40 & 18.67 & 15.09 & 28.63 \\
\hline Opercle Spreads & 1.60 & 22.15 & 8.73 & 14.27 \\
\hline Avoids & $4.90 *$ & 0.46 & 0.84 & 0.98 \\
\hline Tota1 & $3294.23 * *$ & 217.34 & 291.42 & 365.85 \\
\hline
\end{tabular}

*Significant $(P<0.05)$ probability of effect.

**Highly significant $(P<0.01)$ probability of effect.

$t_{\text {Run }}$ effect refers to variation between individual bioassays. 


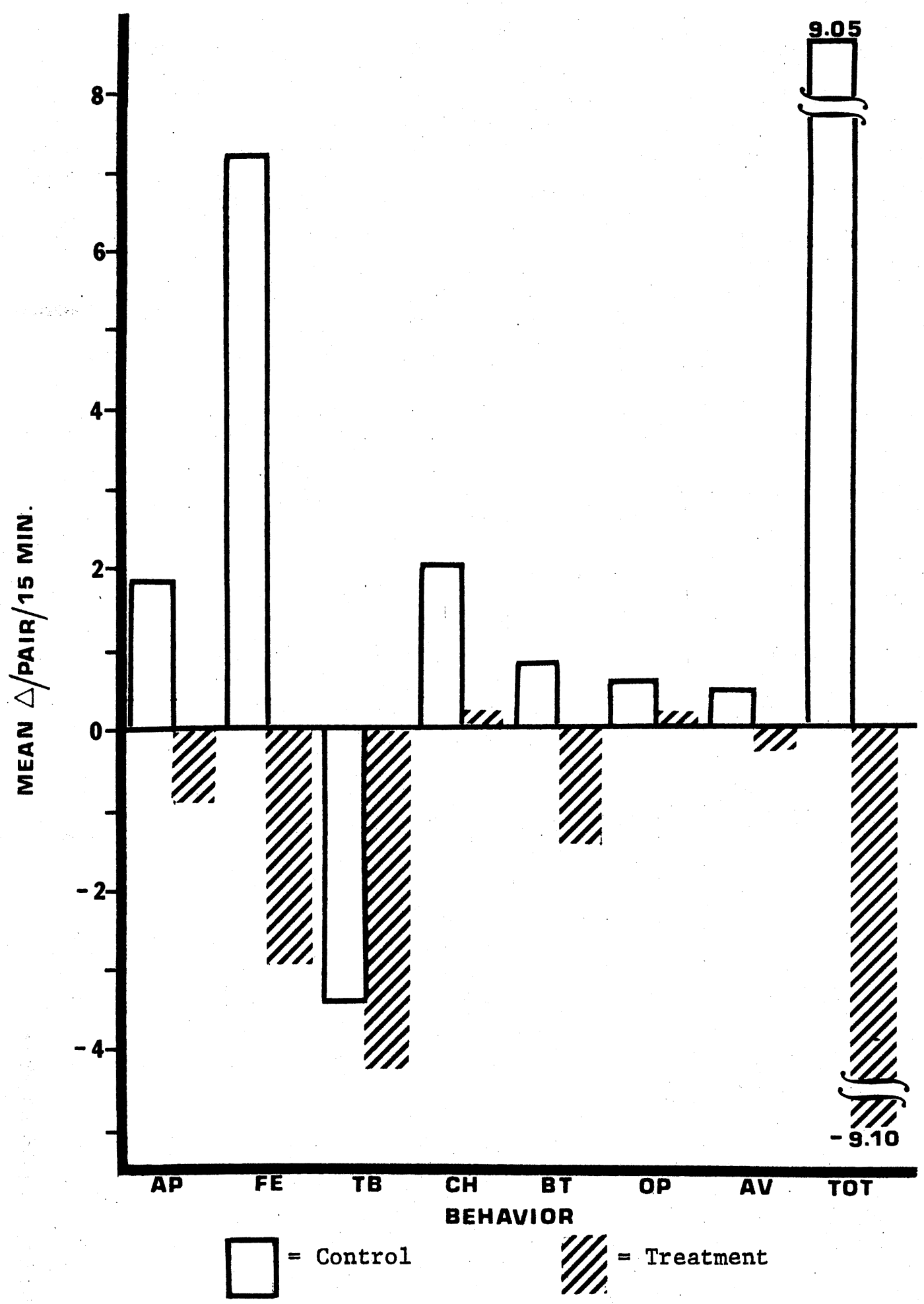

Figure 4. Mean Treatment and Control $\Delta$ Values After 15 Minutes of Observation 
Bioassay 1--1ate October Bioassay 2--mid-October Bioassay 3--late October Bioassay 4--mid-December
Bioassay 5--early March

Bioassay 6--mid-May

Bioassay 7--early July

Bioassay 8--early August
Approaches

Fin erections

Tall beats

Chases

Bites

Opercle spreads

Avoids

Totals

$7 \quad 3$

3

7

7

8

-

5

1

3

$2 \quad 4$

$\begin{array}{lllllllll}7 & 8 & 1 & 5 & 6 & 3 & 2 & 4\end{array}$

8

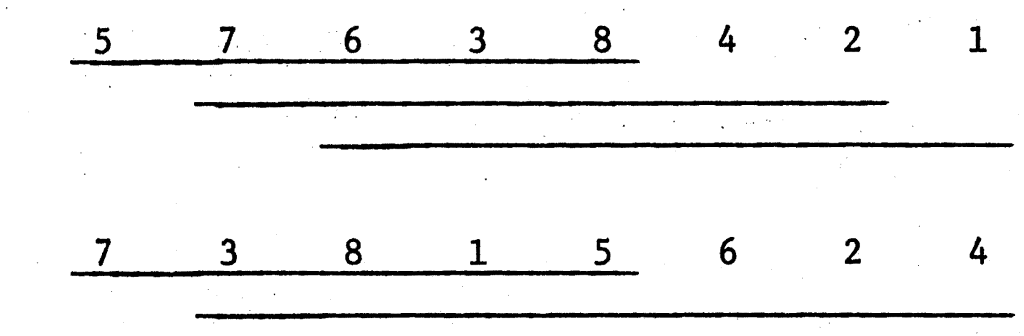

5.7

6

2

3

3

$4 \quad 1$

Higher Mean Frequency

Lower Mean Frequency

Any two means not underscored by the same line are significantly different $(P<0.05)$.

Figure 5. Seasonal Comparison of Behavioral Frequencies 
bioassays also. These observations are mentioned here to illustrate that there are other effects of sublethal petroleum refinery wastewaters on orangespotted sunfish and to provide possible insights for future researchers.

The wastewater used in Bioassay 4 was lethal to five fish. Several stress symtpoms were noticed after fish had been exposed to the wastewater for less than one hour. The wastewater was quickly diluted at that time by adding 6 liters of control water to the 15 liters of wastewater. The most noticeable stress symptoms were loss of equilibrium, exaggerated ventilatory movements, and gulping at the water surface (even though D.O. concentration was $6.4 \mathrm{mg} / 1$ and $\mathrm{CO}_{2}$ concentration was 3-4 mg/1). They also were extremely sensitive to sounds and movements, darting away very quickly when the sides of the aquaria were tapped with a finger. Occasional erratic swimming and loss of bouyancy were observed. By the end of the second day stress symptoms were reduced and no mortalities occurred after that time.

After a wastewater exposure of only six days, two pairs of fish were observed for a one hour period. These fish had not been previously paired with each other so there was no "baseline" with which to compare this observation. Agonistic behavior of these fish was limited primarily to approaches, and to fin erections which were generally not very pronounced. Also, the usual orange to red iris coloration was totally lacking in all four fish. Aside from lack of iris coloration and low agonistic behavior frequency, none of the four fish appeared to be stressed by the wastewater.

During Bioassay 5 five deaths occurred between the third day and tenth day of exposure to the wastewater. No evident stress behavior, 
other than lethargy, was observed before the deaths.

During Bioassay 6, two deaths occurred. Both fish died during the tenth day of exposure and were in the same aquarium. As in Bioassay 4, $\mathrm{CO}_{2}$ and D.O. concentrations should not have been lethal. None of the other fish of the bioassay appeared to be unusually stressed.

During the wastewater exposure periods of most of the bioassays, treatment fish appeared to be less willing to accept food. This was especially true during the first few days of an exposure.

Physicochemical Parameters

\section{Calculation of Daily Means}

Various parameters were measured daily in each of the three control and three treatment aquaria. Other parameters were measured in the six aquaria on alternate days, or only in treatment aquaria at the beginning and end of the wastewater exposure period. For each day that a parameter was measured, a daily mean for control aquaria and a daily mean for treatment aquaria were calculated by summing the three measurements and dividing by three.

\section{Temperature}

Water temperature was measured daily in all three control aquaria and in all three treatment aquaria (Table V). During the eight bioassays the temperatures ranged from 16.1 to $27.5^{\circ} \mathrm{C}$ in the control aquaria and from 16.0 to $27.8^{\circ} \mathrm{C}$ in the treatment aquaria. The difference between the means of the control aquaria and the treatment aquaria on any one day was never more than $1.4^{\circ} \mathrm{C}$. 
TABLE V

MEAN DAILY TEMPERATURE IN BIOASSAY AQUARIA

\begin{tabular}{|c|c|c|c|c|c|c|c|c|c|c|c|}
\hline \multirow{3}{*}{$\begin{array}{l}\text { Bio- } \\
\text { assay } \\
\text { Number }\end{array}$} & \multirow{3}{*}{$\begin{array}{c}\text { Control } \\
\text { or } \\
\text { Treatment }\end{array}$} & \multicolumn{10}{|c|}{ Day } \\
\hline & & 11 & 12 & 13 & 14 & 15 & 16 & 17 & 18 & 19 & 20 \\
\hline & & & & & & ${ }^{\circ} \mathrm{C}$ ( $\pm \mathrm{S}$ & $=$ d. Dev.) & & & & \\
\hline 1 & $\begin{array}{l}\text { (C) } \\
(\mathrm{T})\end{array}$ & - & $\begin{array}{l}21.0 \pm .1 \\
20.9 \pm .1\end{array}$ & $\begin{array}{l}20.8 \pm .6 \\
20.2 \pm .1\end{array}$ & $\begin{array}{l}19.3 \pm .1 \\
19.0 \pm .0\end{array}$ & - & $\begin{array}{l}21.1 \pm .2 \\
20.8 \pm .0\end{array}$ & $\begin{array}{l}22.0 \pm .0 \\
22.0 \pm .0\end{array}$ & $\begin{array}{l}21.0 \pm .0 \\
21.0 \pm .0\end{array}$ & $\begin{array}{l}21.0 \pm .5 \\
21.0 \pm .2\end{array}$ & $\begin{array}{l}21.3 \pm .2 \\
21.0 \pm .0\end{array}$ \\
\hline 2 & $\begin{array}{l}\text { (C) } \\
\text { (T) }\end{array}$ & - & - & - & - & $\begin{array}{l}20.8 \pm .8 \\
20.5 \pm .4\end{array}$ & - & $\begin{array}{l}22.0 \pm .1 \\
21.5 \pm .5\end{array}$ & $\begin{array}{l}22.7 \pm .3 \\
22.0 \pm .7\end{array}$ & - & $\begin{array}{l}21.3 \pm .2 \\
20.9 \pm .2\end{array}$ \\
\hline 3 & $\begin{array}{l}\text { (C) } \\
\text { (T) }\end{array}$ & $\begin{array}{l}22.9 \pm .2 \\
22.2 \pm .2\end{array}$ & - & $\begin{array}{l}23.4 \pm .4 \\
23.0 \pm .1\end{array}$ & $\begin{array}{l}21.5 \pm .0 \\
21.0 \pm .0\end{array}$ & $\begin{array}{l}19.0 \pm .1 \\
18.9 \pm .2\end{array}$ & - & - & - & - & $\begin{array}{l}19.9 \pm .0 \\
19.8 \pm .2\end{array}$ \\
\hline 4 & $\begin{array}{l}(\mathrm{C}) \\
(\mathrm{T})\end{array}$ & $\begin{array}{l}18.9 \pm .0 \\
19.3 \pm .2\end{array}$ & $19 . \overline{8} \pm .4$ & - & - & $19 . \overline{4} \pm .5$ & - & - & - & - & - \\
\hline 5 & $\begin{array}{l}\text { (C) } \\
\text { (T) }\end{array}$ & - & - & - & - & - & $\begin{array}{l}17.7 \pm 1.0 \\
16.3 \pm .4\end{array}$ & - & - & $\begin{array}{l}16.6 \pm .5 \\
17.8 \pm .3\end{array}$ & $\begin{array}{l}17.4 \pm .5 * \\
17.0 \pm .5 *\end{array}$ \\
\hline 6 & $\begin{array}{l}\text { (C) } \\
(\mathrm{T})\end{array}$ & $\begin{array}{l}20.4 \pm .4 \\
20.6 \pm .1\end{array}$ & - & $\begin{array}{l}21.0 \pm .1 \\
21.0 \pm .1\end{array}$ & $\begin{array}{l}21.4 \pm .3 \\
21.1 \pm .1\end{array}$ & $\begin{array}{l}22.2 \pm .3 \\
22.0 \pm .0\end{array}$ & $\begin{array}{l}22.1 \pm .1 \\
21.8 \pm .2\end{array}$ & $\begin{array}{l}22.0 \pm .1 \\
21.9 \pm .1\end{array}$ & $\begin{array}{l}22.3 \pm .4 \\
22.0 \pm .1\end{array}$ & $\begin{array}{l}22.1 \pm .3 \\
22.0 \pm .1\end{array}$ & $\begin{array}{l}22.2 \pm .1 \\
21.4 \pm .6\end{array}$ \\
\hline 7 & $\begin{array}{l}(\mathrm{C}) \\
(\mathrm{T})\end{array}$ & $\begin{array}{l}23.5 \pm .0 \\
23.4 \pm .1\end{array}$ & $\begin{array}{l}23.9 \pm .1 \\
23.5 \pm .3\end{array}$ & $\begin{array}{l}23.0 \pm .1 \\
23.4 \pm .0\end{array}$ & $\begin{array}{l}25.0 \pm .1 \\
25.0 \pm .0\end{array}$ & $\begin{array}{l}27.3 \pm .4 \\
27.5 \pm .5\end{array}$ & $\begin{array}{l}25.6 \pm .4 \\
26.2 \pm .1\end{array}$ & $\begin{array}{l}22.5 \pm .4 \\
23.0 \pm .1\end{array}$ & $\begin{array}{l}22.9 \pm .1 \\
22.7 \pm .2\end{array}$ & $\begin{array}{l}23.9 \pm 1.0 \\
23.0 \pm .0\end{array}$ & $\begin{array}{l}22.4 \pm .1 \\
22.5 \pm .1\end{array}$ \\
\hline 8 & $\begin{array}{l}\text { (C) } \\
\text { (T) }\end{array}$ & $\begin{array}{l}21.3 \pm .3 \\
21.3 \pm .1\end{array}$ & $\begin{array}{l}21.7 \pm .2 \\
21.4 \pm .1\end{array}$ & $\begin{array}{l}21.2 \pm .2 \\
21.2 \pm .0\end{array}$ & $\begin{array}{l}21.0 \pm .0 \\
21.3 \pm .1\end{array}$ & - & $\begin{array}{l}21.6 \pm .2 \\
21.8 \pm .2\end{array}$ & $\begin{array}{l}21.7 \pm .0 \\
20.9 \pm .4\end{array}$ & $\begin{array}{l}22.7 \pm 1.0 \\
21.8 \pm .2\end{array}$ & $\begin{array}{l}23.1 \pm .2 \\
23.7 \pm .1\end{array}$ & $\begin{array}{l}21.1 \pm .1 \\
21.6 \pm .1\end{array}$ \\
\hline
\end{tabular}

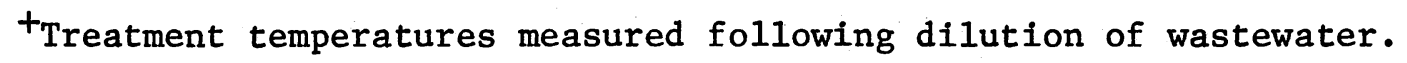

*Temperatures measured on Day 21. 
Dissolved Oxygen

Dissolved oxygen concentrations ranged from 4.0 to $8.2 \mathrm{mg} / 1$ in the control aquaria and from 1.8 to $8.6 \mathrm{mg} / 1$ in the treatment aquaria during the eight bioassays (Table VI). In most cases the D.0. of the wastewater was less than that of the control. The maximum difference between control and treatment aquaria means on a single day was $3.1 \mathrm{mg} / 1$. Generally there was a decrease in D.0. in both control and treatment aquaria during Days 11 through 21. The water replenishments made on alternate days usually temporarily reversed the decrease in D.0. The decrease in D.0. was more pronounced in the treatment aquaria. Aeration was used only on one occasion and then only for approximately five minutes.

The D.0. concentrations in the treatment aquaria of the most lethal bioassays (Bioassays 4,5 and 6 ) were not considered to be directly responsible for mortality since they compared favorably with concentrations measured in non-lethal bioassays. However, low D.0. concentrations have been reported to increase toxicity of various pollutants such as lead, copper, zinc, phenols, and ammonia (Lloyd, 1961; Pickering, 1968).

\section{Conductivity}

Conductivity ranged from 480 to $620 \mu \mathrm{mhos} / \mathrm{cm}$ in the control aquaria and from 1990 to $3003 \mu$ mhos/cm in the treatment aquaria during the eight bioassays (Table VII). The conductivity generally increased during the 10 days that it was monitored. Since conductivity is related to ionic concentration this would be expected to occur as a result of evaporation. 
TABLE VI

MEAN DAILY DISSOLVED OXYGEN CONCENTRATION IN BIOASSAY AQUARIA

\begin{tabular}{|c|c|c|c|c|c|c|c|c|c|c|c|}
\hline \multirow{3}{*}{$\begin{array}{l}\text { Bio- } \\
\text { assay } \\
\text { Number }\end{array}$} & \multirow{3}{*}{$\begin{array}{l}\text { Control } \\
\text { or } \\
\text { Treatment }\end{array}$} & \multicolumn{10}{|c|}{ Day } \\
\hline & & 11 & 12 & 13 & 14 & 15 & 16 & 17 & 18 & 19 & 20 \\
\hline & & & & & & $\mathrm{mg} / 1( \pm \mathrm{s}$ & Std. Dev. & & & & \\
\hline 1 & $\begin{array}{l}\text { (C) } \\
(\mathrm{T})\end{array}$ & - & $\begin{array}{l}6.4 \pm .1 \\
6.1 \pm .3\end{array}$ & $\begin{array}{l}7.0 \pm .1 \\
5.5 \pm .1\end{array}$ & $\begin{array}{l}6.9 \pm .1 \\
5.7 \pm .1\end{array}$ & - & $\begin{array}{l}6.6 \pm .2 \\
5.7 \pm .1\end{array}$ & $\begin{array}{l}6.1 \pm .2 \\
4.7 \pm .1\end{array}$ & $\begin{array}{l}6.1 \pm .2 \\
4.7 \pm .1\end{array}$ & $\begin{array}{l}5.9 \pm .1 \\
4.9 \pm .2\end{array}$ & $\begin{array}{l}5.6 \pm .4 \\
4.7 \pm .2\end{array}$ \\
\hline 2 & $\begin{array}{l}(\mathrm{C}) \\
(\mathrm{T})\end{array}$ & - & - & - & - & $\begin{array}{l}6.3 \pm .1 \\
6.0 \pm .0\end{array}$ & - & $\begin{array}{l}6.4 \pm .2 \\
6.2 \pm .0\end{array}$ & $\begin{array}{l}7.0 \pm .1 \\
6.4 \pm .2\end{array}$ & - & $\begin{array}{l}6.7 \pm .1 \\
5.6 \pm .7\end{array}$ \\
\hline 3 & $\begin{array}{l}\text { (C) } \\
\text { (T) }\end{array}$ & - & - & $\begin{array}{l}6.5 \pm .1 \\
4.9 \pm .5\end{array}$ & $\begin{array}{l}6.4 \pm .0 \\
4.2 \pm .2\end{array}$ & $\begin{array}{l}6.8 \pm .2 \\
5.0 \pm .5\end{array}$ & - & - & $\begin{array}{l}- \\
-\end{array}$ & - & $\begin{array}{l}6.8 \pm .1 \\
4.3 \pm .7\end{array}$ \\
\hline 4 & $\begin{array}{l}\text { (C) } \\
\text { (T) }\end{array}$ & $\begin{array}{l}8.2 \pm .0 \\
6.7 \pm .1\end{array}$ & $6.7 \pm .1$ & - & $3.9 \pm .9$ & $5.8 \pm .4$ & - & - & - & - & - \\
\hline 5 & $\begin{array}{l}\text { (C) } \\
\text { (T) }\end{array}$ & - & - & - & $\begin{array}{l}- \\
-\end{array}$ & - & $\begin{array}{l}7.5 \pm .4 \\
7.3 \pm .4\end{array}$ & - & - & $\begin{array}{l}7.9 \pm .4 \\
6.5 \pm .2\end{array}$ & $\begin{array}{l}7.2 \pm .4 * \\
5.9 \pm 1.0 *\end{array}$ \\
\hline 6 & $\begin{array}{l}\text { (C) } \\
\text { (T) }\end{array}$ & $\begin{array}{l}7.6 \pm .2 \\
8.5 \pm .1\end{array}$ & - & $\begin{array}{l}6.9 \pm .1 \\
6.4 \pm .4\end{array}$ & $\begin{array}{l}6.8 \pm .2 \\
5.8 \pm .5\end{array}$ & $\begin{array}{l}6.4 \pm .1 \\
5.3 \pm .3\end{array}$ & $\begin{array}{r}5.4 \pm .3 \\
-3.6 \pm .1\end{array}$ & $\begin{array}{l}5.8 \pm .3 \\
4.1 \pm .1\end{array}$ & $\begin{array}{l}5.6 \pm .1 \\
3.6 \pm .2\end{array}$ & $\begin{array}{l}5.9 \pm .1 \\
4.4 \pm .2\end{array}$ & $\begin{array}{l}5.6 \pm .1 \\
4.1 \pm .3\end{array}$ \\
\hline 7 & $\begin{array}{l}(\mathrm{C}) \\
(\mathrm{T})\end{array}$ & $\begin{array}{l}6.9 \pm .2 \\
5.3 \pm .3\end{array}$ & $\begin{array}{l}6.0 \pm .4 \\
5.1 \pm .3\end{array}$ & $\begin{array}{l}6.2 \pm .3 \\
5.1 \pm .2\end{array}$ & $\begin{array}{l}5.6 \pm .1 \\
4.4 \pm .6\end{array}$ & $\begin{array}{l}4.3 \pm .2 \\
2.9 \pm 1.0\end{array}$ & $\begin{array}{l}4.1 \pm .1 \\
2.3 \pm .5\end{array}$ & $\begin{array}{l}5.0 \pm .2 \\
2.4 \pm .1\end{array}$ & $\begin{array}{l}5.2 \pm .1 \\
2.2 \pm .0\end{array}$ & $\begin{array}{l}5.4 \pm .2 \\
2.3 \pm .5\end{array}$ & $\begin{array}{l}5.5 \pm .2 * * \\
3.4 \pm 1.5 * *\end{array}$ \\
\hline 8 & $\begin{array}{l}\text { (C) } \\
\text { (T) }\end{array}$ & $\begin{array}{l}6.6 \pm .1 \\
6.3 \pm .2\end{array}$ & $\begin{array}{l}6.5 \pm .1 \\
6.2 \pm .2\end{array}$ & $\begin{array}{l}6.6 \pm .1 \\
6.1 \pm .4\end{array}$ & $\begin{array}{l}6.3 \pm .1 \\
5.7 \pm .4\end{array}$ & - & $\begin{array}{l}5.6 \pm .1 \\
4.6 \pm .9\end{array}$ & $\begin{array}{l}6.0 \pm .1 \\
4.8 \pm .9\end{array}$ & $\begin{array}{l}5.7 \pm .1 \\
4.3 \pm .6\end{array}$ & $\begin{array}{l}5.6 \pm .1 \\
4.0 \pm .7\end{array}$ & $\begin{array}{l}5.5 \pm .1 \\
3.7 \pm 1.0\end{array}$ \\
\hline
\end{tabular}

$+6.4^{\circ} \mathrm{C}$ prior to dilution.

*Measured on Day 21.

**Measured following five minutes of aeration. 
TABLE VII

MEAN DAILY CONDUCTIVITY IN BIOASSAY AQUARIA

\begin{tabular}{|c|c|c|c|c|c|c|c|c|c|c|c|}
\hline \multirow{3}{*}{$\begin{array}{l}\text { Bio- } \\
\text { assay } \\
\text { Number }\end{array}$} & \multirow{3}{*}{$\begin{array}{c}\text { Control } \\
\text { or } \\
\text { Treatment }\end{array}$} & \multicolumn{10}{|c|}{ Day } \\
\hline & & 11 & 12 & 13 & 14 & 15 & 16 & 17 & 18 & 19 & 20 \\
\hline & & \multicolumn{10}{|c|}{$\mu \mathrm{mhos} / \mathrm{cm}( \pm$ Std. Dev. $)$} \\
\hline 1 & $\begin{array}{l}\text { (C) } \\
(\mathrm{T})\end{array}$ & - & - & $\begin{array}{r}482 \pm 2 \\
2000 \pm 0\end{array}$ & $\begin{array}{r}481 \pm 2 \\
2007 \pm 6\end{array}$ & - & $\begin{array}{l}587 \pm 25 \\
2043 \pm 6\end{array}$ & $\begin{array}{c}597+6 \\
2110 \pm 10\end{array}$ & $\begin{array}{r}560+17 \\
2475 \pm 21\end{array}$ & $\begin{array}{l}567 \pm 12 \\
2050 \pm 0\end{array}$ & $\begin{array}{l}577 \pm 12 \\
2110 \pm 0\end{array}$ \\
\hline 2 & $\begin{array}{l}\text { (C) } \\
(\mathrm{T})\end{array}$ & - & - & - & - & $\begin{array}{r}557 \pm 29 \\
2330 \pm 30\end{array}$ & - & $\begin{array}{r}590 \pm 0 \\
2403 \pm 6\end{array}$ & $\begin{array}{c}590+0 \\
2457 \pm 21\end{array}$ & - & $\begin{array}{r}583 \pm 12 \\
2443 \pm 42\end{array}$ \\
\hline 3 & $\begin{array}{l}\text { (C) } \\
(\mathrm{T})\end{array}$ & $\begin{array}{r}533 \pm 6 \\
2303 \pm 6\end{array}$ & - & $\begin{array}{c}567 \pm 6 \\
2390 \pm 10\end{array}$ & $\begin{array}{r}560+0 \\
2390 \pm 6\end{array}$ & $\begin{array}{c}510+0 \\
2210 \pm 10\end{array}$ & - & - & - & - & $\begin{array}{l}543 \pm 15 \\
2260 \pm 0\end{array}$ \\
\hline 4 & $\begin{array}{l}\text { (C) } \\
(\mathrm{T})\end{array}$ & $\begin{array}{c}500+0 \\
2013 \pm 32^{+}\end{array}$ & - & - & - & $2110 \pm 10$ & - & - & - & - & - \\
\hline 5 & $\begin{array}{l}\text { (C) } \\
(\mathrm{T})\end{array}$ & - & - & - & - & - & $\begin{array}{r}573+31 \\
2750 \pm 87\end{array}$ & - & - & $\begin{array}{c}590+36 \\
2920+147\end{array}$ & $\begin{array}{c}590+26 * \\
3003 \pm 159 *\end{array}$ \\
\hline 6 & $\begin{array}{l}\text { (C) } \\
(\mathrm{T})\end{array}$ & - & - & $\begin{array}{r}490+0 \\
2400 \pm 0\end{array}$ & $\begin{array}{c}580 \pm 0 \\
2443 \pm 12\end{array}$ & $\begin{array}{r}583 \pm 6 \\
2497 \pm 6\end{array}$ & $\begin{array}{r}587 \pm 6 \\
2507 \pm 6\end{array}$ & $\begin{array}{r}583 \pm 6 \\
2500 \pm 0\end{array}$ & $\begin{array}{c}590+0 \\
2533 \pm 21\end{array}$ & $\begin{array}{r}513 \pm 6 \\
2107 \pm 6\end{array}$ & $\begin{array}{c}570 \pm 0 \\
2587 \pm 23\end{array}$ \\
\hline 7 & $\begin{array}{l}\text { (C) } \\
(\mathrm{T})\end{array}$ & $\begin{array}{c}510 \pm 0 \\
2013 \pm 12\end{array}$ & $\begin{array}{r}500 \pm 0 \\
2020 \pm 0\end{array}$ & $\begin{array}{r}500 \pm 0 \\
2070 \pm 0\end{array}$ & $\begin{array}{l}510 \pm 0 \\
2150 \pm 0\end{array}$ & $\begin{array}{r}580+20 \\
2267 \pm 12\end{array}$ & $\begin{array}{l}580+10 \\
2253 \pm 6\end{array}$ & $\begin{array}{c}507 \pm 6 \\
2110 \pm 10\end{array}$ & $\begin{array}{r}513 \pm 6 \\
2107 \pm 6\end{array}$ & $\begin{array}{l}510 \pm 0 \\
2110 \pm 0\end{array}$ & $\begin{array}{c}520 \pm 0 \\
2110 \pm 10\end{array}$ \\
\hline 8 & $\begin{array}{l}(\mathrm{C}) \\
(\mathrm{T})\end{array}$ & $\begin{array}{c}507 \pm 6 \\
2407 \pm 12\end{array}$ & $\begin{array}{r}510+0 \\
2427 \pm 6\end{array}$ & $\begin{array}{c}510+0 \\
2460 \pm 10\end{array}$ & $\begin{array}{r}510+0 \\
2480 \pm 0\end{array}$ & - & $\begin{array}{r}520 \pm 0 \\
2520 \pm 0\end{array}$ & $\begin{array}{c}533+6 \\
2480 \pm 17\end{array}$ & $\begin{array}{c}570 \pm 0 \\
2587 \pm 23\end{array}$ & $\begin{array}{c}597 \pm 6 \\
2710 \pm 20\end{array}$ & $\begin{array}{c}583 \pm 6 \\
2607 \pm 12\end{array}$ \\
\hline
\end{tabular}

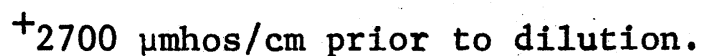

*Measured on Day 21. 
The wastewaters used in Bloassays 4 and 5 were the most toxic, each lethal to five fish, and also were at least 200 to $300 \mu \mathrm{mhos} / \mathrm{cm}$ higher in conductivity than the wastewaters used in the other bioassays. The importance of this is questionable since, depending on the ions involved, a conductivity of $3000 \mu \mathrm{mhos} / \mathrm{cm}$ is not extremely high even for naturally occurring waters.

$\mathrm{pH}$

During the eight bioassays, $\mathrm{pH}$ ranged from 7.2 to 8.7 in control aquaria and from 6.2 to 8.7 in the treatment aquaria (Table VIII). The $\mathrm{pH}$ in control aquaria was almost always higher than the $\mathrm{pH}$ of the wastewater aquaria. Both the control water and the wastewater decreased in $\mathrm{pH}$ during the 10 day period.

\section{Alkalinity}

In all cases total alkalinity was determined to be due to bicarbonate ions since no hydroxide or carbonate ions were indicated by phenolpthalein titrations. Total alkalinity ranged from 137 to $160 \mathrm{mg} / 1$ in the control aquaria and from 4 to $102 \mathrm{mg} / 1$ in treatment aquaria (Table IX). Alkalinity of control water was nearly constant over the 10 day period while the alkalinity of the wastewaters generally decreased.

Hardness

The water hardness ranged from 176 to $229 \mathrm{mg} / 1$ in the control aquaria and from 345 to $470 \mathrm{mg} / 1$ in the treatment aquaria (Table X). 
TABLE VIII

MEAN DAILY PH IN BIOASSAY AQUARIA

\begin{tabular}{|c|c|c|c|c|c|c|c|c|c|c|c|}
\hline \multirow{3}{*}{$\begin{array}{l}\text { Bio- } \\
\text { assay } \\
\text { Number }\end{array}$} & \multirow{3}{*}{$\begin{array}{l}\text { Control } \\
\text { or } \\
\text { Treatment }\end{array}$} & \multicolumn{10}{|c|}{ Day } \\
\hline & & 11 & 12 & 13 & 14 & 15 & 16 & 17 & 18 & 19 & 20 \\
\hline & & & & & & ( \pm Std & Dev.) & & & & \\
\hline 1 & $\begin{array}{l}\text { (C) } \\
\text { (T) }\end{array}$ & - & - & $\begin{array}{l}8.2 \pm .1 \\
7.5 \pm .2\end{array}$ & $\begin{array}{l}8.0 \pm .2 \\
7.2 \pm .1\end{array}$ & - & $\begin{array}{l}8.0+.2 \\
7.2 \pm .1\end{array}$ & $\begin{array}{l}8.0+.2 \\
7.1 \pm .2\end{array}$ & $\begin{array}{l}8.0 \pm .1 \\
7.2 \pm .1\end{array}$ & $\begin{array}{l}8.0 \pm .1 \\
7.2 \pm .1\end{array}$ & $\begin{array}{l}7.9 \pm .1 \\
7.0 \pm .2\end{array}$ \\
\hline 2 & $\begin{array}{l}\text { (C) } \\
\text { (T) }\end{array}$ & - & - & - & - & $\begin{array}{l}8.0+.1 \\
7.4 \pm .1\end{array}$ & - & $\begin{array}{l}8.1 \pm .0 \\
7.4 \pm .1\end{array}$ & $\begin{array}{l}8.1 \pm .0 \\
7.3 \pm .1\end{array}$ & $\begin{array}{l}8.1 \pm .0 \\
7.2 \pm .1\end{array}$ & $\begin{array}{l}8.0 \pm .1 \\
7.0 \pm .1\end{array}$ \\
\hline 3 & $\begin{array}{l}\text { (C) } \\
\text { (T) }\end{array}$ & $\begin{array}{l}8.1 \pm .2 \\
7.4 \pm .1\end{array}$ & - & $\begin{array}{l}7.8 \pm .2 \\
7.2 \pm .1\end{array}$ & $\begin{array}{l}8.1 \pm .1 \\
7.0 \pm .2\end{array}$ & $\begin{array}{l}8.0 \pm .1 \\
7.0 \pm .1\end{array}$ & - & - & - & - & $\begin{array}{l}8.0 \pm .1 \\
6.3 \pm .2\end{array}$ \\
\hline 4 & $\begin{array}{l}\text { (C) } \\
\text { (T) }\end{array}$ & $7.5 \pm .0^{+}$ & $7.6 \pm .1$ & $\overline{-}$ & - & - & - & - & - & - & - \\
\hline 5 & $\begin{array}{l}\text { (C) } \\
\text { (T) }\end{array}$ & - & - & - & - & - & - & - & - & - & - \\
\hline 6 & $\begin{array}{l}\text { (C) } \\
\text { (T) }\end{array}$ & $\begin{array}{l}8.4 \pm .1 \\
8.6 \pm .1\end{array}$ & - & $\begin{array}{l}8.0+.2 \\
7.3 \pm .1\end{array}$ & $\begin{array}{l}7.9+.1 \\
6.8 \pm .1\end{array}$ & $\begin{array}{l}7.8+.1 \\
6.7 \pm .1\end{array}$ & $\begin{array}{l}7.8+.1 \\
6.5 \pm .1\end{array}$ & $\begin{array}{l}7.9+.1 \\
6.4 \pm .1\end{array}$ & $\begin{array}{l}7.8+.1 \\
6.4 \pm .1\end{array}$ & $\begin{array}{l}7.8+.1 \\
6.4 \pm .1\end{array}$ & $\begin{array}{l}7.8+.1 \\
6.3 \pm .1\end{array}$ \\
\hline 7 & $\begin{array}{l}\text { (C) } \\
\text { (T) }\end{array}$ & $\begin{array}{l}8.5 \pm .0 \\
8.2 \pm .1\end{array}$ & $\begin{array}{l}8.6 \pm .1 \\
8.2 \pm .0\end{array}$ & $\begin{array}{l}8.6 \pm .1 \\
8.2 \pm .0\end{array}$ & $\begin{array}{l}8.5 \pm .1 \\
8.1 \pm .1\end{array}$ & $\begin{array}{l}8.5 \pm .1 \\
7.9 \pm .1\end{array}$ & $\begin{array}{l}8.5 \pm .0 \\
7.9 \pm .1\end{array}$ & $\begin{array}{l}8.4 \pm .0 \\
7.7 \pm .2\end{array}$ & $\begin{array}{l}8.5 \pm .0 \\
7.7 \pm .1\end{array}$ & $\begin{array}{l}8.5 \pm .0 \\
7.6 \pm .0\end{array}$ & $\begin{array}{l}7.8 \pm .0 \\
6.9 \pm .0\end{array}$ \\
\hline 8 & $\begin{array}{l}\text { (C) } \\
\text { (T) }\end{array}$ & $\begin{array}{l}8.0 \pm .0 \\
7.3 \pm .0\end{array}$ & $\begin{array}{l}7.9 \pm .1 \\
7.3 \pm .1\end{array}$ & $\begin{array}{l}7.9 \pm .1 \\
7.3 \pm .1\end{array}$ & $\begin{array}{l}8.0 \pm .0 \\
7.3 \pm .1\end{array}$ & - & $\begin{array}{l}7.8 \pm .0 \\
7.3 \pm .0\end{array}$ & $\begin{array}{l}7.2 \pm .0 \\
6.8 \pm .3\end{array}$ & $\begin{array}{l}7.8 \pm .0 \\
6.8 \pm .3\end{array}$ & $\begin{array}{l}7.8 \pm .1 \\
6.7 \pm .3\end{array}$ & $\begin{array}{l}7.6 \pm .1 \\
6.7 \pm .5\end{array}$ \\
\hline
\end{tabular}

$+_{7.2}$ prior to dilution. 
TABLE IX

MEAN DAILY TOTAL ALKALINITY IN BIOASSAY AQUARIA ${ }^{+}$

\begin{tabular}{|c|c|c|c|c|c|c|}
\hline \multirow{3}{*}{$\begin{array}{l}\text { Bioassay } \\
\text { Number }\end{array}$} & \multirow{3}{*}{$\begin{array}{l}\text { Control } \\
\text { or } \\
\text { Treatment }\end{array}$} & \multicolumn{5}{|c|}{ Day } \\
\hline & & 11 & 13 & 15 & 17 & 19 \\
\hline & & \multicolumn{5}{|c|}{$\mathrm{mg} / 1$ as $\mathrm{CaCO}_{3}( \pm$ Std. Dev.) } \\
\hline 1 & $\begin{array}{l}\text { (C) } \\
\text { (T) }\end{array}$ & $\begin{array}{r}150 \pm 2 \\
21 \pm 1\end{array}$ & $\begin{array}{r}154+2 \\
24 \pm 1\end{array}$ & $\begin{array}{c}149 \pm 10 * \\
23 \pm 2 *\end{array}$ & $\begin{array}{r}155 \pm 1 \\
25 \pm 1\end{array}$ & $\begin{array}{r}156+1 \\
23 \pm 1\end{array}$ \\
\hline 2 & $\begin{array}{l}\text { (C) } \\
(\mathrm{T})\end{array}$ & - & - & $\begin{array}{r}150 \pm 0 \\
35 \pm 0\end{array}$ & $\begin{array}{r}157 \pm 0 * \\
34 \pm 1 *\end{array}$ & $\begin{array}{r}159+1 \\
31 \pm 3\end{array}$ \\
\hline 3 & $\begin{array}{l}\text { (C) } \\
\text { (T) }\end{array}$ & $\begin{array}{r}145 \pm 1 \\
35 \pm 1\end{array}$ & $\begin{array}{r}149 \pm 1 \\
31 \pm 2\end{array}$ & $\begin{array}{r}152 \pm 1 \\
26 \pm 7\end{array}$ & - & $\frac{152 \pm 2}{7 \pm 5}$ \\
\hline 4 & $\begin{array}{l}\text { (C) } \\
\text { (T) }\end{array}$ & ${ }_{65}^{-}+0^{++}$ & $66 \pm 2 * *$ & $\begin{array}{l}- \\
-\end{array}$ & - & $\begin{array}{l}- \\
-\end{array}$ \\
\hline 5 & $\begin{array}{l}\text { (C) } \\
\text { (T) }\end{array}$ & - & - & - & - & - \\
\hline 6 & $\begin{array}{l}\text { (C) } \\
\text { (T) }\end{array}$ & $\begin{array}{r}153 \pm 1 \\
24 \pm 1\end{array}$ & $\begin{array}{r}153 \pm 3 \\
19 \pm 2\end{array}$ & $\begin{array}{r}158+2 \\
19+5\end{array}$ & $\begin{array}{r}155 \pm 0 \\
11 \pm 1\end{array}$ & $\begin{array}{r}157 \pm 1 \\
11 \pm 2\end{array}$ \\
\hline 7 & $\begin{array}{l}\text { (C) } \\
\text { (T) }\end{array}$ & $\begin{array}{c}147 \pm 4 \\
88 \pm 12\end{array}$ & $\begin{array}{r}144 \pm 2 \\
82 \pm 2\end{array}$ & $\begin{array}{c}146+1 \\
77 \pm 11\end{array}$ & $\begin{array}{r}147 \pm 1 \\
64 \pm 2\end{array}$ & $\begin{array}{r}151 \pm 1 \\
57 \pm 9\end{array}$ \\
\hline 8 & $\begin{array}{l}\text { (C) } \\
\text { (T) }\end{array}$ & $\begin{array}{r}146 \pm 1 \\
52 \pm 2\end{array}$ & $\begin{array}{r}149+1 \\
52 \pm 2\end{array}$ & - & $\begin{array}{c}157 \pm 2 \\
41 \pm 13\end{array}$ & $\begin{array}{c}159+1 \\
34 \pm 18\end{array}$ \\
\hline
\end{tabular}

+No carbonate or hydroxide alkalinity indicated by titration. $+_{32}$ mg/1 prior to dilution.

*Measured one day later than indicated.

**Measured one day earlier than indicated. 
TABLE $\mathrm{X}$

MEAN DAILY HARDNESS IN BIOASSAY AQUARIA

\begin{tabular}{|c|c|c|c|c|c|c|}
\hline \multirow{3}{*}{$\begin{array}{l}\text { Bioassay } \\
\text { Number }\end{array}$} & \multirow{3}{*}{$\begin{array}{c}\text { Control } \\
\text { or } \\
\text { Treatment }\end{array}$} & \multicolumn{5}{|c|}{ Day } \\
\hline & & 11 & 13 & 15 & 17 & 19 \\
\hline & & & $\mathrm{mg} / 1$ as & $\mathrm{CO}_{3}( \pm \mathrm{std}$ & Dev.) & \\
\hline 1 & $\begin{array}{l}(\mathrm{C}) \\
(\mathrm{T})\end{array}$ & $\begin{array}{l}223 \pm 7 \\
399 \pm 43\end{array}$ & $\begin{array}{l}199 \pm 5 \\
356 \pm 6\end{array}$ & $\begin{array}{l}221 \pm 8 * \\
358 \pm 14 *\end{array}$ & $\begin{array}{l}197 \pm 5 \\
356 \pm 6\end{array}$ & $\begin{array}{l}197 \pm 8 \\
358 \pm 5\end{array}$ \\
\hline 2 & $\begin{array}{l}\text { (C) } \\
\text { (T) }\end{array}$ & - & - & $\begin{array}{l}188 \pm 0 \\
395 \pm 9\end{array}$ & $\begin{array}{l}201 \pm 5 * \\
418 \pm 9 *\end{array}$ & $\begin{array}{l}212 \pm 4 \\
413 \pm 8\end{array}$ \\
\hline 3 & $\begin{array}{l}\text { (C) } \\
(\mathrm{T})\end{array}$ & $\begin{array}{l}200+4 \\
383 \pm 5\end{array}$ & $\begin{array}{l}197 \pm 5 \\
388 \pm 4\end{array}$ & $\begin{array}{l}200 \pm 4 \\
384 \pm 4\end{array}$ & - & $\begin{array}{l}202 \pm 4 * \\
400 \pm 4 *\end{array}$ \\
\hline 4 & $\begin{array}{l}\text { (C) } \\
(\mathrm{T})\end{array}$ & $349 \pm 0^{+}$ & $383 \pm 8 * *$ & - & - & - \\
\hline 5 & $\begin{array}{l}\text { (C) } \\
(\mathrm{T})\end{array}$ & - & - & - & - & - \\
\hline 6 & $\begin{array}{l}\text { (C) } \\
(\mathrm{T})\end{array}$ & $\begin{array}{l}203 \pm 2 \\
402 \pm 16\end{array}$ & $\begin{array}{l}200 \pm 4 \\
399 \pm 12\end{array}$ & $\begin{array}{l}212+12 \\
404 \pm 11\end{array}$ & $\begin{array}{l}211+5 \\
403 \pm 2\end{array}$ & $\begin{array}{l}214 \pm 8 \\
470 \pm 0\end{array}$ \\
\hline 7 & $\begin{array}{l}\text { (C) } \\
(\mathrm{T})\end{array}$ & $\begin{array}{l}184 \pm 0 \\
368 \pm 4\end{array}$ & $\begin{array}{l}188 \pm 4 \\
380 \pm 4\end{array}$ & $\begin{array}{l}191 \pm 2 \\
381 \pm 6\end{array}$ & $\begin{array}{l}193+2 \\
391 \pm 6\end{array}$ & $\begin{array}{l}203+8 \\
389 \pm 2\end{array}$ \\
\hline 8 & $\begin{array}{l}(\mathrm{C}) \\
(\mathrm{T})\end{array}$ & $\begin{array}{l}182 \pm 6 \\
391 \pm 2\end{array}$ & $\begin{array}{l}188 \pm 0 \\
395 \pm 2\end{array}$ & - & $\begin{array}{l}201 \pm 2 \\
418 \pm 8\end{array}$ & $\begin{array}{l}207 \pm 2 \\
413 \pm 6\end{array}$ \\
\hline
\end{tabular}

$+412 \mathrm{mg} / 1$ prior to dilution.

*Measured one day later than indicated.

**Measured one day earlier than indicated. 
The hardness of both control water and wastewater generally increased during the 10 day period.

Carbon Dioxide

During the eight bioassays $\mathrm{CO}_{2}$ concentration ranged from 0.4 to $15.9 \mathrm{mg} / 1$ in control aquaria and from 0.1 to $13.6 \mathrm{mg} / 1$ in treatment aquaria (Table XI). Concentrations were generally higher in treatment aquaria and increased with time in both treatment and control aquaria.

\section{Total Organic Carbon}

During the eight bioassays total organic carbon concentrations in treatment aquaria on Day 11 ranged from 8.02 to $196.82 \mathrm{mg} / 1$ (Table XII). TOC concentration on Day 21 ranged from 8.62 to $77.60 \mathrm{mg} / 1$. Comparison of TOC with number of deaths indicates a possible but inconsistent correlation between TOC and mortality in the bioassays. TOC concentrations were greater than $20 \mathrm{mg} / 1$ in three of the four bioassays in which mortality occurred. Concentrations greater than $20 \mathrm{mg} / 1$ were measured in all three of the bioassays which, because of excessive mortality, were not considered in statistical comparisons of agonistic behavior changes. The high TOC concentrations measured during Bioassay 6 were partially a result of a large population of phytoplankton. Only one of the four bioassays in which no mortalities occurred had a TOC concentration greater than $20 \mathrm{mg} / 1$. Burks and Wilhm (1978) reported a correlation between TOC and fathead minnow mortality which was better than any correlation that could be shown between mortality and ammonia or metals. 
TABLE XI

MEAN DAILY $\mathrm{CO}_{2}$ CONCENTRATION IN BIOASSAY AQUARIA

\begin{tabular}{|c|c|c|c|c|c|c|}
\hline \multirow{3}{*}{$\begin{array}{l}\text { Bioassay } \\
\text { Number }\end{array}$} & \multirow{3}{*}{$\begin{array}{l}\text { Control } \\
\text { or } \\
\text { Treatment }\end{array}$} & \multicolumn{5}{|c|}{ Day } \\
\hline & & 11 & 13 & 15 & 17 & 19 \\
\hline & & \multicolumn{5}{|c|}{$\mathrm{mg} / 1( \pm$ Std. Dev.) } \\
\hline 1 & $\begin{array}{l}\text { (C) } \\
\text { (T) }\end{array}$ & - & $\begin{array}{l}1.7 \pm .3 \\
1.4 \pm .5\end{array}$ & $\begin{array}{l}2.5 \pm .8 * \\
2.2 \pm .7 *\end{array}$ & $\begin{array}{l}2.5 \pm .6 \\
2.7 \pm .6\end{array}$ & $\begin{array}{l}2.2 \pm .3 \\
2.6 \pm 1.0\end{array}$ \\
\hline 2 & $\begin{array}{l}\text { (C) } \\
(\mathrm{T})\end{array}$ & - & - & $\begin{array}{l}2.1 \pm .2 \\
2.4 \pm .4\end{array}$ & $\begin{array}{l}2.0 \pm .0 * \\
2.4 \pm .4 *\end{array}$ & $\begin{array}{l}2.0 \pm .0 \\
3.1 \pm .4\end{array}$ \\
\hline 3 & $\begin{array}{l}\text { (C) } \\
\text { (T) }\end{array}$ & $\begin{array}{l}1.8 \pm .6 \\
2.2 \pm .5\end{array}$ & $\begin{array}{l}3.8 \pm 1.9 \\
3.4 \pm .6\end{array}$ & $\begin{array}{l}2.6 \pm .4 \\
4.0 \pm 1.1\end{array}$ & - & $\begin{array}{l}2.5 \pm .6 * \\
5.7 \pm 2.9\end{array}$ \\
\hline 4 & $\begin{array}{l}\text { (C) } \\
\text { (T) }\end{array}$ & $3.0 \pm .0^{+}$ & $3.0 \pm .5 * *$ & - & - & - \\
\hline 5 & $\begin{array}{l}\text { (C) } \\
(\mathrm{T})\end{array}$ & - & - & - & - & - \\
\hline 6 & $\begin{array}{l}\text { (C) } \\
(\mathrm{T})\end{array}$ & $\begin{array}{l}1.0 \pm .2 \\
0.1 \pm .0\end{array}$ & $\begin{array}{l}2.8 \pm .9 \\
1.6 \pm .3\end{array}$ & $\begin{array}{l}3.8 \pm 1.1 \\
6.1 \pm 2.4\end{array}$ & $\begin{array}{l}3.4 \pm .5 \\
6.8 \pm 1.3\end{array}$ & $\begin{array}{l}4.0 \pm 1.0 \\
6.7 \pm .5\end{array}$ \\
\hline 7 & $\begin{array}{l}\text { (C) } \\
(\mathrm{T})\end{array}$ & $\begin{array}{l}0.7 \pm .0 \\
1.0 \pm .1\end{array}$ & $\begin{array}{l}0.6 \pm .2 \\
0.8 \pm .0\end{array}$ & $\begin{array}{l}0.8 \pm .1 \\
1.4 \pm .2\end{array}$ & $\begin{array}{l}0.9 \pm .0 \\
1.9 \pm .1\end{array}$ & $\begin{array}{l}0.8 \pm .0 \\
2.2 \pm .4\end{array}$ \\
\hline 8 & $\begin{array}{l}\text { (C) } \\
\text { (T) }\end{array}$ & $\begin{array}{l}2.3 \pm .1 \\
4.2 \pm .1\end{array}$ & $\begin{array}{l}3.2 \pm .4 \\
4.3 \pm .4\end{array}$ & - & $\begin{array}{c}15.7 \pm .2 \\
9.6 \pm 3.6\end{array}$ & $\begin{array}{l}4.3 \pm .6 \\
9.6 \pm 1.7\end{array}$ \\
\hline
\end{tabular}

$+3.6 \mathrm{mg} / 1$ prior to dilution.

*Measured one day later than indicated.

**Measured one day earlier than indicated. 
TABLE XII

MEAN TOTAL ORGANIC CARBON AND NUMBER OF MORTALITIES IN TREATMENT AQUARIA

\begin{tabular}{cccc}
\hline $\begin{array}{c}\text { Bioassay } \\
\text { Number }\end{array}$ & Day 11 & TOC (mg/1) & $\begin{array}{c}\text { Number of } \\
\text { Mortalities }\end{array}$ \\
\cline { 2 - 4 } 1 & $18.57 \pm 2.53$ & $17.01 \pm 2.30$ & 0 \\
2 & - & $31.23 \pm 16.9$ & 0 \\
3 & $18.21 \pm 1.77$ & $18.55 \pm 0.21$ & 0 \\
4 & $31.93^{+}, 47.05 \pm 1.03$ & - & $5 *$ \\
5 & $33.86 \pm 21.13$ & $25.16 \pm 4.99$ & 5 \\
6 & $104.16 \pm 81.29$ & $46.26 \pm 27.35$ & 2 \\
7 & $13.19 \pm 3.28$ & $10.19 \pm 1.22$ & 1 \\
8 & $9.58 \pm 2.27$ & $10.36 \pm 2.97$ & 0 \\
\hline
\end{tabular}

${ }_{\text {TOC }}$ of diluted wastewater on Day 12. Second number is TOC of undiluted wastewater taken from a collection jar on Day 12 .

*Wastewater was diluted after approximately one hour when severe stress was noticed. Mortalities occurred in the diluted wastewater. (15 liters wastewater:6 liters control water). 
Heavy Metals

Total chromium concentrations in water sampled from treatment aquaria during the bioassays ranged from $<0.02 \mathrm{mg} / 1$ to $0.15 \mathrm{mg} / 1$ (Table XIII). Highest concentrations were found in the three most lethal bioassays. Pickering and Henderson (1966) obtained static hardwater (360 $\mathrm{mg} / 1) 96 \mathrm{~h}$ bioassay LC50 values of approximately $30 \mathrm{mg} / 1$ for fathead minnows and $133 \mathrm{mg} / 1$ for bluegill sunfish. A proposed EPA criterion for freshwater aquatic life is $0.1 \mathrm{mg} / 1$ (EPA, 1976).

Total lead concentrations ranged from $<0.01 \mathrm{mg} / 1$ to $0.02 \mathrm{mg} / 1$. Concentrations found in water collected from the three most lethal bioassays were as low or lower than concentrations found in non-lethal bioassays. Pickering and Henderson (1966) report a 96 h LC50 of 482 $\mathrm{mg} / 1$ for fathead minnows in hardwater static bioassays. For rainbow trout (Salmo gairdneri) in hardwater $(300 \mathrm{mg} / 1)$, the $96 \mathrm{~h} \mathrm{LC50}$ was found to be $471 \mathrm{mg} / 1$ total lead and $1.38 \mathrm{mg} / 1$ dissolved lead (Davies and Everhart, 1973). A proposed EPA criterion for freshwater is 0.01 times the $96 \mathrm{~h}$ LC50 of soluble lead using a sensitive resident species (EPA, 1976).

Total zinc concentrations (Day 21) ranged from 0.02 to $0.46 \mathrm{mg} / 1$ during the elght bioassays. Again the highest concentrations occurred in the water sampled from the most toxic bioassays. Pickering and Henderson (1966) found the $96 \mathrm{~h}$. LC50 of fathead minnows in hardwater to be $33 \mathrm{mg} / 1$. A proposed EPA criterion for freshwater is 0.01 times the 96 h LC50 of a sensitive resident species. 
TABLE XIII

MEAN CHROMIUM, LEAD, AND ZINC CONCENTRATIONS AND NUMBER OF MORTALITIES IN TREATMENT AQUARIA

\begin{tabular}{clccc}
\hline $\begin{array}{c}\text { Bioassay } \\
\text { Number }\end{array}$ & \multicolumn{1}{c}{$\mathrm{Cr}$} & $\mathrm{mg} / 1^{*}$ & $\begin{array}{c}\text { Number of } \\
\text { Mortalities }\end{array}$ \\
\cline { 2 - 5 } 1 & $0.03 \pm .02$ & $0.02 \pm .01$ & $0.09 \pm .05$ & 0 \\
2 & $0.04 \pm .01$ & $0.01 \pm .01$ & $0.11 \pm .05$ & 0 \\
3 & $0.04 \pm .01$ & $<0.01$ & $0.08 \pm .00$ & 0 \\
4 & $0.12^{+}$ & $<0.01^{+}$ & $0.46^{+}$ & $5^{+}$ \\
& $0.14 \pm .01$ & $<0.01$ & $0.11 \pm .01$ & \\
5 & $0.04 \pm .01$ & $<0.01$ & $0.20 \pm .03$ & 5 \\
6 & $0.04 \pm .01$ & $0.01 \pm .01$ & $0.13 \pm .02$ & 2 \\
7 & $0.02 \pm .00$ & $0.02 \pm .02$ & $0.03 \pm .00$ & 1 \\
8 & $0.03 \pm .01$ & $<0.01$ & $0.03 \pm .01$ & 0 \\
& & & & \\
\end{tabular}

*Total metal concentrations in treatment aquaria on Day 21 of Bioassays $1,2,3,5,6,7$ and 8 and on Day 12 of Bioassay 4 .

${ }^{+}$Concentration in diluted wastewater. Second concentration is of non-diluted wastewater taken from a collection jar on Day 12 .

+Wastewater was diluted after approximately one hour when severe stress was noticed. Mortalities occurred in the diluted wastewater (15 liters wastewater:6 liters control water). 
CHAPTER IV

CONCLUSIONS

The methods used were able to detect decreases in the frequency of several agonistic behaviors as a result of exposure to a sublethal concentration of a biologically treated petroleum refinery wastewater. Statistically significant decreases were found in frequencies of approaches, fin erections, chases, bites and avoids. A parameter composed of all seven behavior types, except avoids, was also significantly affected. For every behavior type and at each of the three temporal levels of observation, the mean $\Delta$ value of the wastewater exposed fish was less than the mean $\Delta$ value of the control fish, even though these differences were not always statistically significant (Figures 2, 3, and 4).

A 15 minute observation period was sufficient to detect changes in agonistic behavior frequencies. This result was unexpected since it seemed that in many cases during the first five minutes of observation the fish were overcoming the disturbance caused by the lifting of the observation aquarium partition.

There is some indication that fish were more active during the summer months and less active during the winter. For most behavior types, the fish used in Bioassay 7 (early July) were the most active and the fish used in Bioassay 4 (mid-December) were the least active. 
Chemical and physical analyses performed during the bioassays revealed that the most lethal bioassays also contained the highest concentrations of chromium, zinc, total organic carbon and also had the highest conductivity readings. 


\section{CHAPTER V}

\section{DISCUSSION AND RECOMMENDATIONS}

Behavioral changes which are potentially deleterious to the organism were detected by the bioassays conducted during this study. Such effects would not have been detected by standard bioassays measuring acute or chronic (up to 10 days) mortality only. While bioassays using acute mortality to measure toxicity of wastewaters serve a useful purpose, it is the responsibility of aquatic biologists to also consider the possibility of sublethal effects of wastewaters. Testing for sublethal effects can be expensive and/or time consuming and therefore is not attractive to industry and biologists involved in monitoring effluents. Changes in growth rates, reproductive rates, mutation rates, etc., may require months to be detected. Equipment needed for conditioned response-learning tests, swimming ability tests, and "cough" response tests probably prohibits more widespread use of these techniques.

The behavioral bioassay technique described in this paper has the advantage of being very inexpensive; it does not require a large amount of expertise, does not require a long exposure period or observation time, and is sensitive. The discovery that two observation periods of only 15 minutes duration were sufficient to detect changes in agonistic behavior improved the attractiveness of this test in terms of sensitivity and time expended. In the simplest case, one observer would be needed 
to record on a data sheet the number of fin erections per pair of fish during the 15 minute observation periods. Even though 15-minute observation periods were adequate, an observation period of 30 minutes may be sufficiently more reliable to compensate for the additional observation time required. It may be desirable in some cases to monitor only one type of behavior. It is felt that the best single behavior to observe would be bites. Bites were significantly affected at both 30 and 60 minutes of observation. Also, at 60 minutes, the frequency of bites was statistically the most significantly affected single behavior. Bites are also the most easily recognized behavior and the least subjectively determined. In contrast, fin erections are more difficult to determine since there is a continuum between fully retracted and fully erect fins.

The ecological significance of a change in agonistic behavior rates is unproven at this time. Indeed there is the possibility that the change itself may not be present in a more natural environment and that it is only a laboratory phenomenon. However, if change in frequency of agonistic behavior did occur following exposure to sublethal wastewaters in receiving streams, these changes would potentially be deleterious because of deviation from a pattern which has evolved as a process of natural selection (Warner et al., 1967). Agonistic behavior is known to be a component of centrarchid spawning behavior (Hunter, 1963; Miller, 1963). Male longear sunfish, Lepomis megalotis megalotis, have been observed using agonistic behaviors such as chases, fin erections, and opercle spreads to drive other longears, largemouth bass, and other bottom feeding fish away from their nests (Witt and Marzolf, 1954; Keenleyside, 1972). Male orangespotted sunfish have been observed 
intruding into the nest of other males to feed on developing embryos (Barney and Anson, 1923).

Conceivably a reduction in frequencies of agonistic behaviors could result in smaller territories--smaller areas defended around the nests of spawning males. If availability of spawning sites is the factor limiting population size, then there would be a potential for an increase in population size. Even if other factors were limiting there would probably be more fry produced. Alternatively, there is the potential loss of more embryos due to intrusions into the nest by other predators if the spawning males were less aggressive. Either of these alternatives, if carried to the extreme, could have a negative effect on the population .

Conditions which may be responsible for alteration of the frequency of agonistic behaviors include subtle changes in color of some body pattern which acts as a "releaser" of aggression by conspecifics (Stacy, 1975), neurophysiological changes, or a decline in general physical condition of the fish.

A comparison of the 60 minute cumulative frequencies of control fish with the cumulative frequencies of the treatment fish indicated that the total number of behaviors exhibited by all treatment fish on Day 10 of the five sublethal bioassays was considerably higher than that exhibited by all control fish. This was surprising since on Day 10 the control and treatment palrs of fish had been treated similarly.

The more frequent activity of the treatment group is not thought to reflect an experimental bias. Fish were paired randomly, designated as treatment or control pairs randomly, and placed in aquaria which had been randomly designated as either treatment or control aquaria. 
It is possible that the higher frequencies found for the treatment group are a result of observer bias--especially for some of the more subjectively determined behaviors. However, the possibility of subjectively "inflated" frequencies for treatment pairs on Day 10 was considered during all bioassays and a constant effort was made to avoid this type of bias. Also, of the 35 possible comparisons ( 7 behavior types $x 5$ sublethal bioassays), the control pairs actually exhibited a given behavior at least as often as the treatment pairs in 16 cases. In Bioassays 3 , 7, and 8 there were a few very active individuals that considerably increased the frequency of agonistic behaviors in the treatment group. These individuals were in part responsible for this unexpected result. The possibility of this type of bias could be eliminated if the observer did not know which pairs were treatment pairs and which were control pairs.

Further investigations of this type could benefit from the use of simultaneous Daphnia bioassays for comparative purposes. The wastewater used for this study was not acutely lethal or chronically lethal over a 10 day period to the sunfish, but a more accurate measure of toxicity using a sensitive organism would be beneficial. Future investigation of the possibility of using shorter exposure periods to reduce the lag time between initial exposure to a pollutant and observation of effect would be helpful. Determination of the effect of observation of wastewater exposed fish in control water should also be made. When investigating effects of pollutants which do not present observation problems because of color exposed fish should be observed in the treatment water to avoid any effect of the transfer from the treatment water to the control water. 
Allee, W.C., B. Greenberg, G.M. Rosenthal and P. Frank. 1948. Some effects of social organization on growth in the green sunfish, Lepomis cyanellus. Jo. Exp. Zoo1. 108:1-19.

APHA (American Public Health Association, American Water Works Association, Water Pollution Control Federation). 1975. Standard methods for the examination of water and wastewater. 14th ed. APHA, Washington. $1193 \mathrm{pp}$.

Baker, J.M. 1976. Experimental investigations of refinery effluents. In Marine ecology and oil pollution (ed. Baker). Wiley and Sons, New York. 566 pp.

Barney, R.L. and B.J. Anson. 1923. Life history and ecology of the orangespotted sunfish, Lepomis humilis. Appendix XV to the Report of the U.S. Commission of Fisheries, 1922. U.S. Department of Commerce, Bureau of Fisheries.

Barr, A.J., J. H. Goodnight, J. P. Sall and J. T. Helwig. 1976. A user's guide to SAS 76. Sparks Press, Raleigh, N.C. 329 pp.

Boyden, C.R., H. Watling and I. Thornton. 1975. Effect of zinc on the settlement of the oyster Crassostrea gigas. Mar. Biol. (Berlin) $31(3): 227-234$.

Boyer, R.L. 1969. Aspects of the behavior and biology of the longear sunfish, Lepomis megalotis (Rafinesque), in two Arkansas reservoirs. M.S. thesis, Oklahoma State University. 103 pp.

Breder, C.M. 1936. The reproductive behavior of the North American sunfishes (Family Centrarchidae). Zoologica 21:1-43.

Bul1, C.J. and J.E. McInerney. 1975. Behavior of juvenile coho salmon (Oncorhyncus kisutch) exposed to Sumithion (fenitrothion), an organophosphate insecticide. Jo. Fish. Res. Bd. Can. 31(12): 1867-1872.

Burks, S.L. and J.L. Wilhm. 1978. Blological evaluation of best practicable and best available treatment control technology for petroleum refinery wastewaters. Available on microfiche as PB-272 281 from Nat1. Tech. Info. Serv., U.S. Dept. Commerce. 46 pp. 
Clark, R.C. and D.W. Brown. 1977. Petroleum: properties and analysis in biotic and abiotic systems. In Effects of petroleum on arctic and subarctic marine environments and organisms. Vo1. I. Nature and fate of petroleum (ed. Malins). Academic Press, New York. $321 \mathrm{pp}$.

Clemens, H.P. and P.B. Summers. 1952. A phase in managing refinery wastes polluting streams. Proc. Okla. Acad. Sci. 33:86-96.

Crook, J.H. 1970. Social organization and the environment: aspects of contemporary social ethology. Anim. Behav. 18(2):197-209.

Davies, P.H. and W.H. Everhart. 1973. Effects of chemical variations in aquatic environments: Vol. III. Lead toxicity to rainbow trout and testing applications factor concept. Environmental Protection Agency, Eco1. Res. Series Report, EPA-R3-73-011.

Davy, F.B., H. Kleerekoper, and J.H. Matis. 1973. Effects of exposure to sublethal DDT on the exploratory behavior of the goldfish (Carassius auratus). Water Resour. Res. 9(4):900-905.

Dennis, G.P. 1970. The effects of group size, fish size, and available space on agonistic behavior during group establishment in the orangespotted sunfish, Lepomis humilis (Girard). M.S. thesis, Oklahoma State University. 31 pp.

Dicks, B. 1973. Some effects of Kuwait crude oil on the limpet, Patella vulgata. Environ. Pollut. 5:219-229.

- 1976. The importance of behavioral patterns in toxicity testing and ecological prediction. In Marine ecology and oil pollution (ed. Baker). Halsted Press, New York. 566 pp.

EPA (Environmental Protection Agency). 1974. Methods for chemical analysis of water and wastes. EPA-625/6-74-003a. $298 \mathrm{pp}$.

\section{$501 \mathrm{pp}$.}

- 1976. Quality criteria for water. EPA-440/9-76-023.

Erickson, J.G. 1967. Social hierarchy and stress reactions in sunfish. Physiol. Zoo1. 40(1):40-48.

Farr, J.A. 1977. Impairment of antipredator behavior in Palaemonetes pugio by exposure to sublethal doses of parathion. Trans. Am. Fish. Soc. 106(1):287-290.

Frey, D.F. and R.J. Miller. 1972. The establishment of dominance relationships in the blue gourami, Trichogaster trichopterus (Pallas). Behav. 42:8-62.

Gould, W.R. 1962. Suitabilities and relative resistances of twelve species of fish as bioassay animals for oil-refinery effluents. $\mathrm{Ph} . \mathrm{D}$. dissertation, Oklahoma State University. $50 \mathrm{pp}$. 
Graham, R.J. 1963. Long-term toxicity bioassay of oll refinery effluents. Ph.D. dissertation, Oklahoma State University. 54 pp. and T.C. Dorris. 1968. Long-term toxicity of bioassay of oil refinery effluents. Water Res. 2:643-663.

Greenberg, B. 1947. Some relations between territory, social hierarchy, and leadership in the green sunfish (Lepomis cyanellus). Physiol. Zool. 20:267-299.

Hadley, W.F. 1969. Factors affecting aggressive behavior and social hierarchy in the longear sunfish, Lepomis megalotis (Rafinesque). $\mathrm{Ph} . \mathrm{D}$. dissertation, Oklahoma State University. 77 pp.

Hale, E.B. 1956. Effects of forebrain lesions on the aggressive behavior of green sunfish, Lepomis cyanellus. Physiol. Zool. $29: 107-127$.

Hunter, J.R. 1963. The reproductive behavior of the green sunfish, Lepomis cyanellus. Zoologica 48:13-24.

Irwin, W.H. 1965. Fifty-seven species of fish in oil refinery bioassay. Trans. No. Am. Wildlife and Nat. Resour. Conf. 30:89-99.

Johnsgard, P.A. 1967. Animal behavior. William C. Brown Co., Dubuque, Iowa. $156 \mathrm{pp}$.

Johnson, F.G. 1977. Sublethal biological effects of petroleum hydrocarbon exposures: bacteria, algae, and invertebrates. In Effects of petroleum on arctic and subarctic marine environments and organisms. Vol. II, Biological effects (ed. Malins). Academic Press, New York. 500 pp.

Johnson, R.N. 1972. Aggression in man and animals. W.B. Saunders Co., Philadelphia. 269 pp.

Kania, H.J. and J. O'Hara. 1974. Behavioral alteration in a simple predator-prey system due to sublethal exposure to mercury. Trans. Am. Fish. Soc. 104:134-136.

Keenleyside, M.H.A. 1972. Intraspecific intrusions into nests of spawning longear sunfish (Pisces:Centrarchidae). Copeia 1972:272278 .

Kleinholz, C.K. 1978. Evaluation of the pollution potential of petroleum refinery wastewater using fathead minnow bioassays. M.S. thesis, Oklahoma State University. $60 \mathrm{pp}$.

Krebs, C.T. and K.A. Burns. 1977. Long term effects of an oil spill on populations of the salt-marsh crab Uca pugnax. Science 197: 484-487. 
Lind, 0.T. 1974. Handbook of common methods on limnology. C.V. Mosby Co., St. Louis. $154 \mathrm{pp}$.

Lloyd, R. 1961. Effect of dissolved oxygen concentrations on the toxicity of several poisons to rainbow trout (Salmo gairdneri Richardson). Jo. Exp. Biol. 38:447-455.

McNicholl, P.G. and W.C. Mackay. 1975a. Effect of DDT and M.S. 222 on learning a simple conditioned response in rainbow trout (Salmo gairdneri). Jo. Fish. Res. Bd. Can. 32(5):661-666.

and - 1975b. Effect of DDT on discriminating ability of rainbow trout (Salmo gairdneri). Jo. Fish. Res. Bd. Can. $32(6): 785-788$.

Miller, H.C. 1963. The behavior of the pumpkinseed sunfish, Lepomis gibbosus (Linneaus), with notes on the behavior of other species of Lepomis and the pygmy sunfish, Elassoma evergladei. Behav. $22: 88-151$.

Miller, R.J. and H.W. Robison. 1973. The fishes of Oklahoma. Oklahoma State University Press, Stillwater, 246 pp.

Parsons, R. 1972. Some sub-lethal effects of refinery effluent upon the winkle, Littorina saxatilis. Oil Pollution Research Unit, Field Studies Council, Annual Report 1972. Pembroke, Wales, Great Britain. (Cited by Dicks, 1976).

Pattern, B.G. 1977. Sublethal biological effects of petroleum hydrocarbon exposures: fish. In Effects of petroleum on arctic and subarctic marine environments and organisms. Vol. II. Biological effects (ed. Malins). Academic Press, New York. 500 pp.

Pickering, 0.H. and C. Henderson. 1966. The acute toxicity of some heavy metals to different species of warm water fishes. Air and Water Pollut. Int. Jo. 10:453-467.

and - 1968. Some effects of dissolved oxygen concentrations upon the toxicity of zinc to bluegill. Lepomis macrochirus Rafinesque. Water Res. 2:187-194.

Powel1, L.E. $19 / 2$. Factors influencing agonistic behavior and social organization in the orangespotted sunfish, Lepomis humilis (Girard). $\mathrm{Ph} . \mathrm{D}$. dissertation, Oklahoma State University. $141 \mathrm{pp}$.

Scherer, E. 1977. Behavioural assays-principles, results, and problems. Proc. 3rd Aquatic Toxicity Workshop, Halifax, N.S., Nov. 2-3, 1976. Environmental Protection Service Technical Report No. EPS-5AR-77-1, Halifax, Canada. pp. 33-40.

Sprague, J.B. 1971. Measurement of pollutant toxicity to fish. III. Sublethal effects and "safe" concentrations. Water Res. 5:245-266. 
- 1976. Current status of sublethal tests of pollutants on aquatic organisms. Jo. Fish. Res. Bd. Can. 33:1988-1992.

, P.F. Elston, and R.L. Saunders. 1965. Sublethal copper-zinc pollution in a salmon river--a field and laboratory study. Air and Water Pollut. Int. Jo. 9:531-543.

, D.W. Rowe, G.F. Westlake, T.A. Heming, and I.T. Brown. 1978. Sublethal effects of treated liquid effluent from a petroleum refinery on freshwater organisms. Environmental Protection Service, Canada. 297 pp.

Stacy, P.B. 1975. Body pattern and the aggressive behavior of pumpkinseed sunfish (Lepomis gibbosus). M.S. thesis, University of Colorado. 68 pp.

Stee1, R.G.D. and J.H. Torrie. 1960. Principles and procedures of statistics. McGraw-Hill, New York. 481 pp.

Sticke1, L.F. 1969. Organochlorine pesticides in the environment. U.S. Bureau of Sport Fisheries and Wildlife, Special Scientific Report No. 119. 32 pp.

Symons, P.E.K. 1973. Behavior of young Atlantic salmon (Salmo salar) exposed to or force-fed fenitrothion, an organophosphate insecticide. Jo. Fish. Res. Bd. Can. 30(5):651-655.

Warner, R.E. 1967. Bio-assays for microchemical environmental contaminants. Bull. World Health Org. 36:181-207.

, K.K. Peterson, and L. Borgman. 1966. Behavioral pathology in fish: A quantitative study of sublethal pesticide toxication. Jo. Appl. Eco1. 3(Supp1.):223-247.

Weir, P.A. and C.H. Hine. 1970. Effects of various metals on behavior of conditioned goldfish. Arch. Env. Health 20:45-51.

Weis, P. and J.S. Weis. 1975. Schooling behavior of Menidia menidia in the presence of the insecticide Sevin (carbary1). Mar. Biol. (Ber1in) 28(4):261-263.

Witt, A. and R.C. Marzolf. 1954. Spawning and behavior of the longear sunfish, Lepomis megalotis megalotis. Copeia 3:188-190. 
APPENDIXES 
APPENDIX A

SAS ANOVA COMPUTER PROGRAM 
SAS ANOVA Computer Program

This program is based on SAS ANOVA (Barr et al., 1976).

//EXEC SASBOTH, REGION. GO $=250 \mathrm{~K}$

//GO. SYSIN DD*

DATA RAW;

INPUT RUN 1 TRT\$3 PAIR 5 FISH\$7 AP1 9-11 AP2 13-15 FE1 17-19 FE2 21-23

TB1 25-27 TB2 29-31 CH1 33-35 CH2 37-39 BT1 41-43 BT2 45-47 OP1 49-51

OP2 53-55 AV1 57-59 AV2 61-63;

$\mathrm{TOT} 1=\mathrm{AP} 1+\mathrm{FE} 1+\mathrm{TB} 1+\mathrm{CH} 1+\mathrm{BT} 1+\mathrm{OP} 1$

TOT $2=\mathrm{AP} 2+\mathrm{FE} 2+\mathrm{TB} 2+\mathrm{CH} 2+\mathrm{BT} 2+\mathrm{OP} 2$;

$\mathrm{AP}=\mathrm{AP} 2-\mathrm{AP} 1 ; \mathrm{FE}=\mathrm{FE} 2-\mathrm{FE} 1 ; \mathrm{TB}=\mathrm{TB} 2-\mathrm{TB} 1 ; \mathrm{CH}=\mathrm{CH} 2-\mathrm{CH} 1 ;$

$\mathrm{BT}=\mathrm{BT} 2-\mathrm{BT} 1 ; \mathrm{OP}=\mathrm{OP} 2-\mathrm{OP} 1 ; \mathrm{AV}=\mathrm{AV} 2-\mathrm{AV} 1 ; \mathrm{TOT}=\mathrm{TOT} 2-\mathrm{TOT} 1 ;$

CARDS ;

(Place data cards here)

PROC SORT DATA = RAW; BY RUN TRT PAIR;

PROC MEANS NOPRINT DATA = RAW; BY RUN TRT PAIR;

OUTPUT OUT $=$ TOT SUM $=$ AP FE TB CH BT OP AV TOT;

VARIABLES AP FE TB CH BT OP AV TOT;

PROC SAS72 DATA = TOT; PARMCARDS 4;

PROC ANOVA; CLASSES RUN TRT PAIR; MEANS/TRT;

MODEL AP FE TB CH BT OP AV TOT = RUN TRT

PAIR (RUN TRT);

TEST RUNITRT BY PAIR(RUN TRT);

$; ; ; ;$ 
APPENDIX B

NUMBER OF BEHAVIORS FOR EACH FISH OBSERVED

AFTER 15 MINUTES OF OBSERVATION 


\begin{tabular}{|c|c|c|c|c|c|c|c|c|c|c|c|c|c|c|c|c|c|c|}
\hline \multicolumn{19}{|c|}{$\begin{array}{l}C \\
0\end{array}$} \\
\hline \multirow{5}{*}{$\begin{array}{l}K \\
U \\
N\end{array}$} & $\mathbf{P}$ & & & & & & EOUF: & ENEY & of & & EHAV & I ORS & AFT & & & & & \\
\hline & $\Delta$ & & & & & & & IST & AN & & ND 1 & $0-D A Y$ & & & & & & \\
\hline & 1 & & & & & & & & & PER & 100 & & & & & & & \\
\hline & & 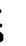 & & $A P$ & & FE & & TB & & & $\mathrm{CH}$ & & BT & & $O P$ & & & iv \\
\hline & 1 & & IST & 2NO & IST & 2ND & IST & $2 \mathrm{NO}$ & & $15 T$ & 2ND & $1 S T$ & 2ND & $1 S T$ & 2ND & & $S T$ & 2ND \\
\hline - & - & $\cdot$ & -- & -- & & -- & & & & & & & & & & & & \\
\hline C & 11 & J & 1 & 0 & 12 & 3 & 0 & 0 & 0 & 0 & 0 & 0 & 0 & 0 & 0 & & 0 & \\
\hline C & 11 & 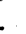 & 2 & 4 & 6 & 8 & 0 & 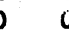 & 0 & 0 & 0 & 0 & 0 & 0 & 0 & & 0 & 0 \\
\hline C & 21 & J & 0 & 0 & 1 & 0 & 0 & 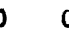 & 0 & 0 & 0 & 0 & 0 & 0 & 0 & & 0 & \\
\hline C & 21 & . & 1 & 1 & 0 & 4 & 1 & $i$ & 0 & 0 & 0 & 1 & 0 & 0 & 0 & & 0 & 0 \\
\hline$c$ & 41 & 1 & 0 & 0 & 2 & 0 & 0 & b & 0 & 0 & 0 & 0 & 0 & 0 & 0 & & 0 & 0 \\
\hline C & 4 & . & 0 & 5 & 5 & 17 & 0 & ) & 0 & 0 & 2 & 0 & 0 & 0 & 0 & & 0 & 0 \\
\hline C & 6 & J & 20 & 4 & 29 & 37 & 12 & & 0 & 4 & 0 & 4 & 6 & 0 & 0 & & 0 & 0 \\
\hline C & 0 & . & 1 & 0 & 15 & 7 & 20 & & 0 & 2 & 0 & 0 & 0 & 0 & 0 & & 0 & 2 \\
\hline & 2 & J & 0 & 0 & 5 & 1 & 0 & ) & 0 & 0 & 0 & 0 & 0 & 0 & 0 & & 0 & 0 \\
\hline$T$ & 2 & 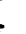 & 0 & 0 & 1 & 2 & 0 & b & 0 & 0 & 0 & 0 & 0 & 0 & 0 & & 0 & \\
\hline$T$ & 3 & J & 1 & 1 & 19 & 10 & 0 & D & 0 & 0 & 0 & 0 & 0 & 0 & 0 & & 0 & 0 \\
\hline $\mathbf{T}$ & 3 & . & 2 & 1 & 15 & 7 & 1 & 1 & 0 & 0 & 0 & 0 & 0 & 0 & 0 & & 0 & 0 \\
\hline$r$ & 4 & J & 0 & 0 & 2 & 3 & 0 & 0 & 0 & 0 & 0 & 0 & 0 & 0 & 0 & & 0 & 0 \\
\hline$T$ & 4 & . & 1 & 5 & 1 & 20 & 0 & o & 0 & 0 & 0 & 0 & 4 & 0 & 0 & & 0 & \\
\hline$T$ & 5 & j & 3 & 1 & 15 & 7 & 2 & ? & 0 & 0 & 0 & 0 & 0 & 0 & 0 & & 0 & \\
\hline$T$ & 5 & & 1 & 0 & 12 & 1 & 0 & 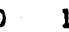 & 1 & 0 & 0 & 0 & 0 & 1 & 0 & & 0 & \\
\hline$i$ & 1 & j & 0 & 2 & 1 & 17 & 0 & ) & 2 & 0 & 7 & 0 & 1 & 0 & 0 & & 0 & 0 \\
\hline$i$ & 1 & . & 0 & 0 & 0 & 3 & 0 & ) & 0 & 0 & 0 & 0 & 0 & 0 & 0 & & 0 & 0 \\
\hline & 2 & j & 0 & 2 & 1 & 11 & 0 & 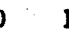 & 1 & 0 & 0 & 0 & 0 & 0 & 4 & & 0 & \\
\hline C & $<$ & & 0 & 2 & 1 & 3 & 0 & 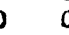 & 0 & 0 & 0 & 0 & 0 & 0 & 0 & & 0 & 0 \\
\hline c & 4 & J & 1 & 0 & 3 & 1 & 0 & b & 0 & 0 & 0 & 0 & 0 & 0 & 0 & & 0 & \\
\hline$c$ & 4 & 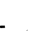 & 1 & 0 & 1 & 0 & 12 & & 2 & 0 & 0 & 0 & 0 & 0 & 0 & & 0 & \\
\hline C & 0 & J & 0 & 2 & 4 & 1 & 0 & ) & 0 & 0 & 0 & 0 & 0 & 0 & 0 & & 0 & 0 \\
\hline$c$ & 6 & 6 & 3 & 1 & 6 & 5 & 0 & 0 & 0 & 0 & 0 & 0 & 0 & 0 & 0 & & 0 & \\
\hline $\boldsymbol{T}$ & 1 & J & 5 & 2 & 16 & 11 & 8 & 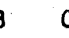 & 0 & 1 & 0 & 1 & 0 & 3 & 0 & & 0 & 0 \\
\hline$r$ & 1 & 6 & 0 & 0 & 7 & 2 & 1 & 1 & 0 & 0 & 0 & 0 & 0 & 0 & 0 & & 0 & \\
\hline$T$ & 2 & J & 0 & 0 & 3 & 9 & 0 & 5 & 6 & 0 & 0 & 0 & 0 & 0 & 0 & & 0 & 0 \\
\hline $\mathbf{T}$ & 2 & 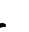 & 0 & 1 & 4 & 9 & 0 & 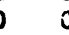 & 0 & 0 & 0 & 0 & 0 & 0 & 0 & & 0 & 0 \\
\hline $\mathbf{T}$ & 4 & J & 1 & 0 & 29 & 10 & 0 & ) & 0 & 0 & 0 & 0 & 0 & 0 & 0 & & 0 & \\
\hline $\mathbf{T}$ & 4 & 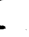 & 0 & 3 & 5 & 3 & 0 & b & 0 & 0 & 0 & 0 & 0 & 0 & 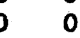 & & 0 & \\
\hline$T$ & $b$ & 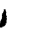 & 1 & 0 & 12 & 17 & 0 & b & 0 & 0 & 0 & 0 & 0 & 0 & 0 & & 0 & \\
\hline$T$ & 5 & & 1 & 0 & 25 & 10 & 0 & ) & 0 & 0 & 0 & 0 & 0 & 0 & 0 & & 0 & \\
\hline$c$ & 2 & J & 0 & 0 & 1 & 1 & 0 & 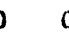 & 0 & 0 & 0 & 0 & 0 & 0 & 0 & & 0 & \\
\hline 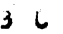 & 2 & 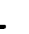 & 0 & 1 & 3 & 3 & $v$ & J & 0 & 0 & 0 & 0 & 0 & 0 & 0 & & 0 & \\
\hline C & 5 & J & 3 & 1 & 11 & 5 & 3 & 3 & 0 & 0 & 0 & 1 & 0 & & 1 & & 0 & \\
\hline C & $b$ & - & 0 & 1 & 10 & 8 & 10 & & 0 & 0 & 0 & 0 & 0 & 0 & 0 & & 0 & \\
\hline C & 6 & J & 2 & 3 & 11 & 19 & 0 & 0 & 0 & 0 & 0 & 0 & 0 & 0 & 0 & & 0 & \\
\hline$c$ & 0 & 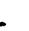 & 1 & 0 & 8 & 8 & 0 & b & 0 & 0 & 0 & 0 & 0 & 0 & 0 & & 0 & 0 \\
\hline C & 4 & J & 2 & 0 & 10 & 17 & 0 & 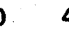 & 4 & 0 & 5 & 0 & 0 & 0 & 0 & & 0 & 0 \\
\hline$c$ & 4 & 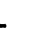 & 0 & 4 & 9 & 23 & 0 & 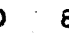 & 8 & 0 & 0 & 0 & 8 & 0 & 1 & & 0 & \\
\hline $\mathbf{T}$ & 4 & J & 1 & 0 & 14 & 3 & 2 & ? & 0 & 0 & 0 & 0 & 0 & 0 & 0 & & 0 & 0 \\
\hline $\boldsymbol{T}$ & 1 & 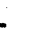 & 0 & 0 & 8 & 10 & 4 & 4 & 0 & 0 & 0 & 0 & 0 & 0 & 0 & & 0 & \\
\hline $\mathbf{T}$ & 2 & J & 10 & 0 & 16 & 3 & 4 & 4 & 0 & 8 & 0 & 3 & 0 & 0 & 0 & & 0 & 0 \\
\hline $\mathbf{T}$ & $<$ & . & 1 & 0 & 1 & 1 & 3 & 3 & 0 & 0 & 0 & 0 & 0 & 0 & 0 & & 2 & \\
\hline$T$ & 4 & J & 0 & 3 & 6 & 9 & 0 & ) & 0 & 0 & 0 & 0 & 0 & 0 & 0 & & 0 & \\
\hline $\boldsymbol{T}$ & 4 & 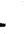 & 1 & 0 & 9 & 8 & 0 & 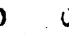 & 0 & 0 & 0 & 0 & 0 & 0 & 0 & & 0 & \\
\hline$T$ & b & J & 2 & 2 & 20 & 21 & 3 & 3 & 0 & 0 & 0 & 0 & 0 & & 0 & & 0 & \\
\hline $\mathbf{T}$ & 5 & & 9 & 1 & 34 & 20 & 1 & 1 & 0 & 0 & 0 & 0 & 0 & 0 & 0 & & 0 & \\
\hline
\end{tabular}




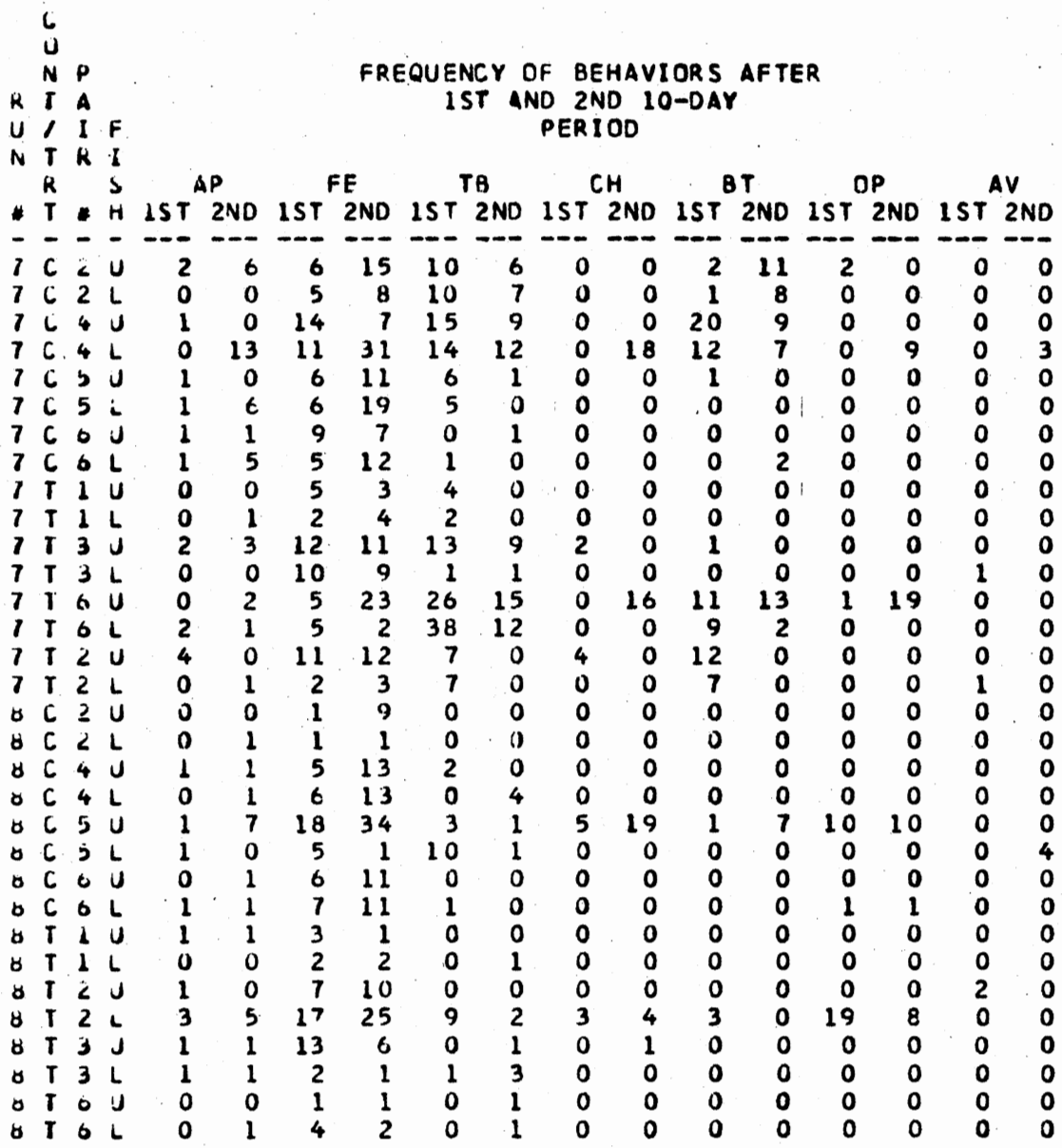


APPENDIX C

NUMBER OF BEHAVIORS FOR EACH FISH OBSERVED

AFTER 30 MINUTES OF OBSERVATION 


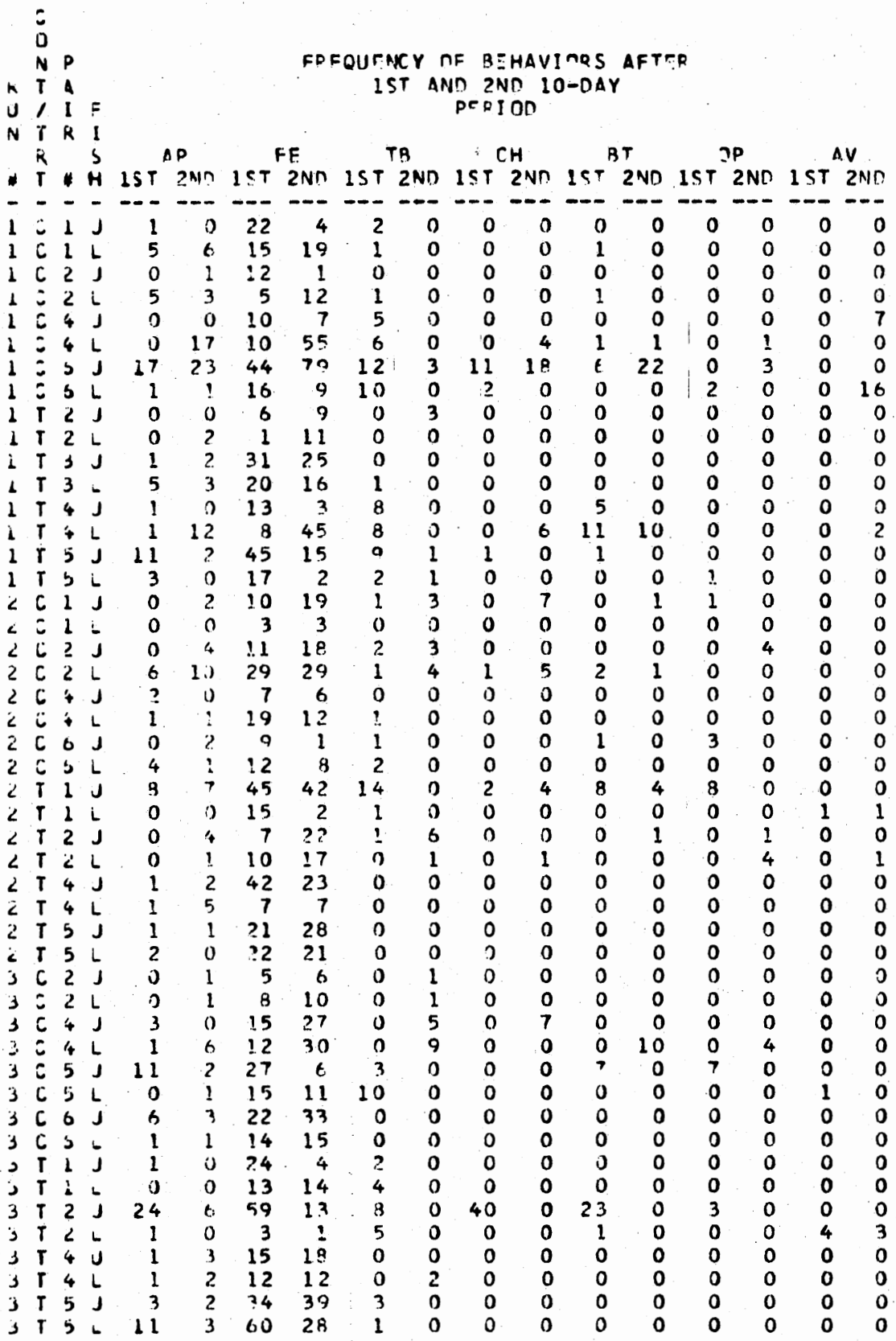




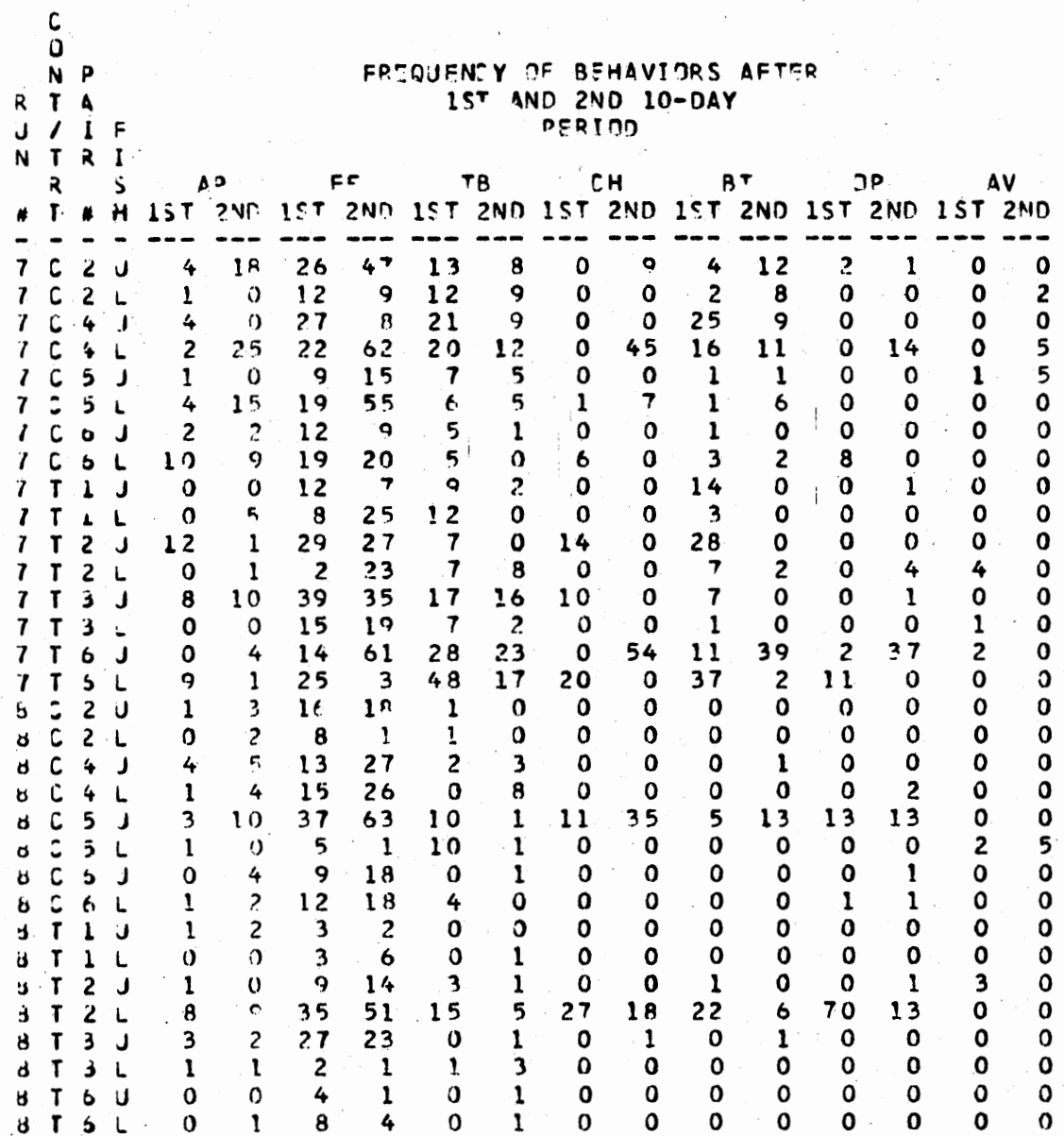


APPENDIX D

NUMBER OF BEHAVIORS FOR EACH FISH OBSERVED AFTER 60 MINUTES OF OBSERVATION 


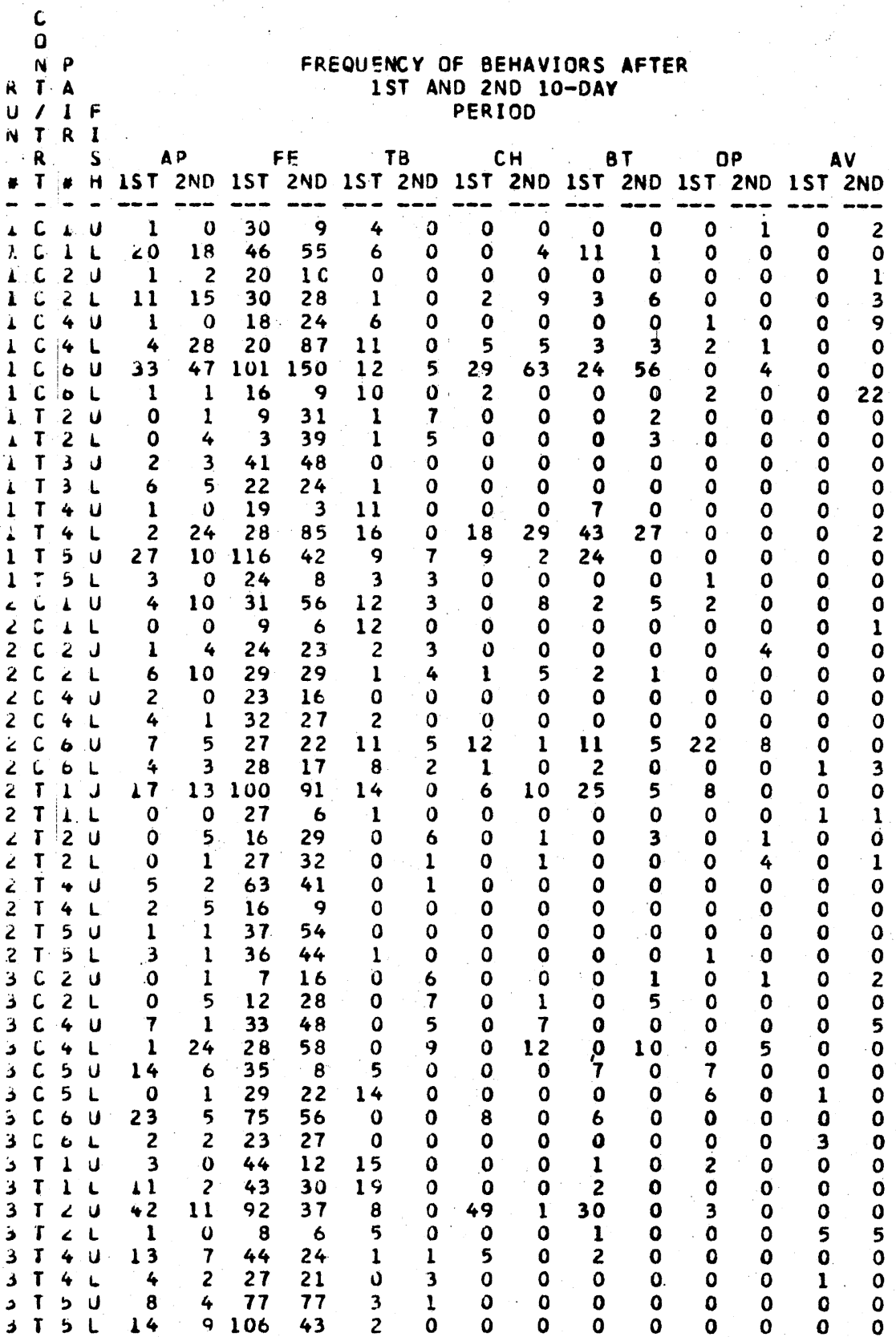




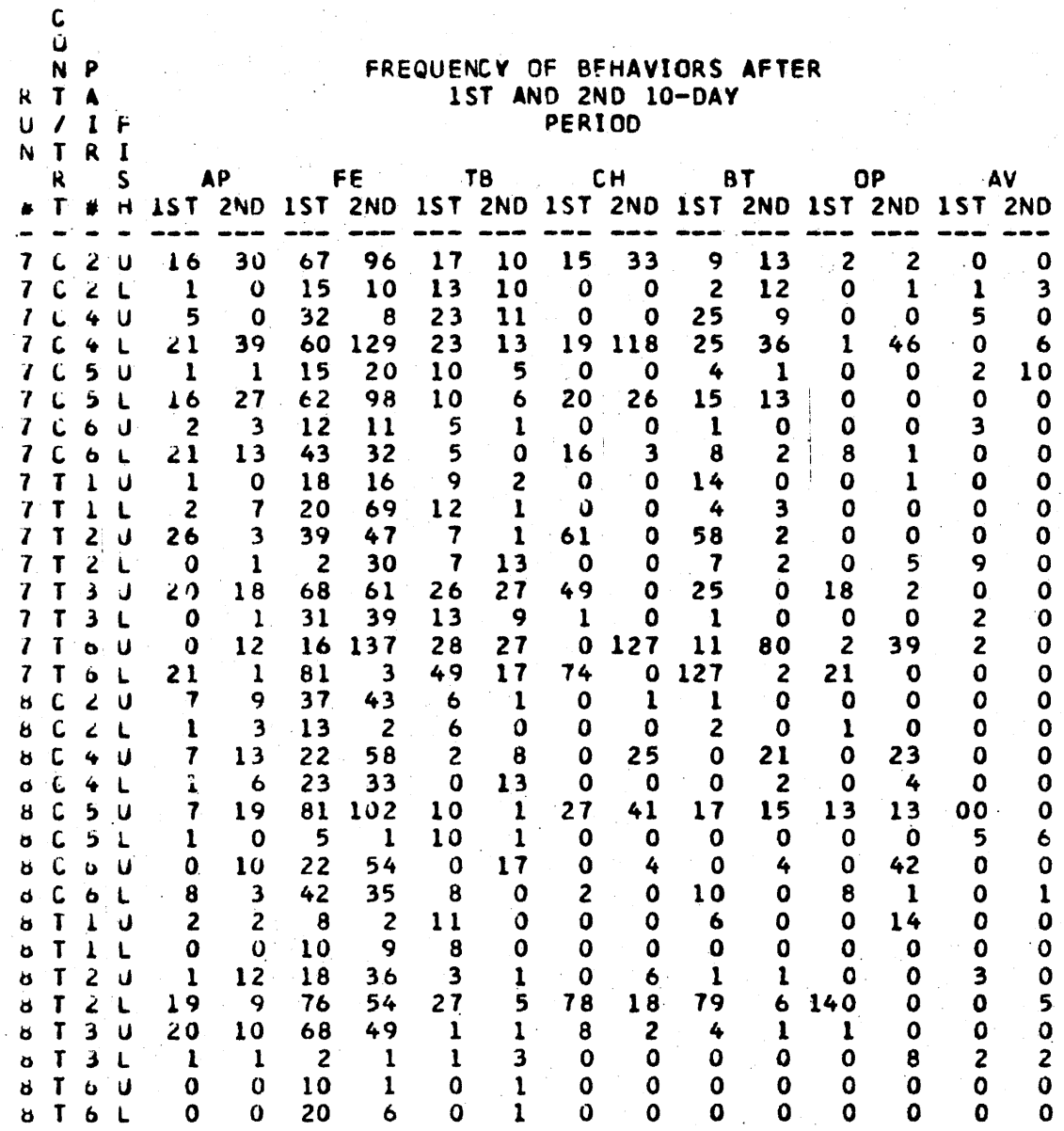




\author{
VITA $^{2}$ \\ James Carrol1 Petersen \\ Candidate for the Degree of \\ Master of Science
}

Thesis: SUBLETHAL EFFECTS OF BIOLOGICALLY TREATED PETROLEUM REFINERY WASTEWATERS ON AGONISTIC BEHAVIOR OF MALE ORANGESPOTTED

SUNFISH, LEPOMIS HUMILIS (GIRARD)

Major Field: Zoology

Biographical:

Personal Data: Born in Hot Springs, South Dakota, November 3, 1952, the son of Alfred and Doris Petersen.

Education: Graduated from Hot Springs High School, Hot Springs, South Dakota, in May, 1971; attended University of Northern Colorado, 1971-73; received Bachelor of Science degree in Biology from University of South Dakota in 1975; completed requirements for the Master of Science degree at Oklahoma State University in December, 1979.

Professional Experience: Forestry aide, South Dakota Department of Game, Fish, and Parks, summers of 1974-76; field technician and graduate research assistant, Oklahoma State University, 197677; graduate research assistant, Reservoir Research Center, Oklahoma State University, 1978; laboratory technician, Aquatic Life Consultants, Inc., Stillwater, Oklahoma, 1978; graduate teaching assistant, Oklahoma State University, 1978-79; graduate research assistant, Oklahoma Cooperative Fisheries Unit, Oklahoma State University, 1979; hydrologist, U.S. Geological Survey, 1979.

Professional Organizations: North American Benthological Society, American Fisheries Society. 